\title{
Color of Tenement Houses Built in the 19th and Early 20th Centuries in Wroclaw (Poland)-Research, Restoration and Conservation
}

\author{
Przemyslaw Nowakowski (D)
}

check for updates

Citation: Nowakowski, Przemyslaw. 2022. Color of Tenement Houses Built in the 19th and Early 20th Centuries in Wroclaw (Poland)-Research, Restoration and Conservation. Arts 11: 27. https://doi.org/10.3390/ arts11010027

Academic Editor: Iñaki Bergera

Received: 19 November 2021

Accepted: 30 January 2022

Published: 7 February 2022

Publisher's Note: MDPI stays neutral with regard to jurisdictional claims in published maps and institutional affiliations.

Copyright: (C) 2022 by the author Licensee MDPI, Basel, Switzerland. This article is an open access article distributed under the terms and conditions of the Creative Commons Attribution (CC BY) license (https:/ / creativecommons.org/licenses/by/ $4.0 /)$.
Faculty of Architecture, Wroclaw University of Science and Technology, 50-317 Wroclaw, Poland; przemyslaw.nowakowski@pwr.edu.pl

\begin{abstract}
The article presents an analysis of the color evolution of tenement houses in Wroclaw in the 19 th and early 20th centuries. Their various colors, confirmed by research, prove the term "Colorful Wroclaw", appearing in the 1930s the architectural journals. The considerations were supported, i.e., by iconographic material presenting the varied colors of renovated tenement houses in Wroclaw. The aim of this analysis is to show the role of scientific and conservation research in restoring the historical value of buildings. Examples of tenement house restoration projects show the practical application of scientific research to formulate conservation guidelines and organize renovation work. Renovation work also requires traditional and increasingly modern construction techniques. These historical buildings belong to the country's cultural heritage. They are usually entered into the Monuments Register and are subject to conservation protection. Restoring their former appearance and character is possible thanks to the participation of national and international institutions. It deals with supporting the flow of knowledge and financial resources. The following research methods were used: archival and literature studies, analytical studies of selected conservation techniques and stratigraphic studies of paint coatings, and case studies when discussing renovation projects for selected tenement houses.
\end{abstract}

Keywords: tenement house; façade color; restoration of historical buildings; architecture of Wroclaw; Poland; 19th and 20th centuries

\section{Introduction}

Wroclaw is one of the oldest and largest cities in Poland. For centuries it belonged to Poland, Czechia and Germany (in the 19th and first half of the 20th century, it belonged to Germany). After World War II (along with the greater part of Lower Silesia), it was incorporated into Poland. Many years were spent rebuilding after the damage sustained during the war. The architectural heritage of the former German and now Polish hosts is clearly visible in the multicolored appearance and multicultural character of historical buildings.

After World War II and the destruction of many European cities, comprehensive rules for the conservation and restoration of architectural monuments were introduced. They were created, among others, as part of international conventions (e.g., the Venice Charter).

For about five decades, the Polish government focused on satisfying housing needs and building new apartments (Błażko and Skrzypek-Łachińska 2004; Kirschke and Kirschke 2017). Improving the condition of the monuments was not a priority at that time. The authorities have become more interested in the condition and restoration of historical tenement houses since the 1990s. Conducting comprehensive conservation work has gained greater importance in recent years. These restoration activities are now even covered by municipal revitalization programs, financed by the Polish state and the European Union. They give an international significance (especially in Central Europe) to the renovation work carried out in Wroclaw, a large European city. 
This article consists of three main parts. The first part briefly discusses the style and color changes of tenement houses in Wroclaw in the 19th and 20th centuries and the conditions for their revalorization nowadays. In the second part, conservation research prior to design and renovation work was analyzed, including the role of stratigraphic research and design methods to recreate color concepts. It is particularly important to define the authentic technique of building, finishing, and colors of a historical building and its structural elements, architectural details, elevations, interiors, etc. (Dokumentowanie Zabytków 2021). The third part presents the process of designing and carrying out the renovation work, taking into account the conservation guidelines. Fragments of the author's façade renovation projects for selected historical tenement houses in Wroclaw were also presented. The projects are an example of the design and implementation of renovation work according to conservation research. They show the possibility of combining theoretical research work with practical construction activities.

\section{Research Goals and Methods, State of Research and its International Importance 2.1. Research Objectives}

The analyses presented in the article indicate the meaning of conservation research in the design of restoration of old buildings. The role of this research is to restore the façade's colors and its historical, aesthetical and technical value. The reconstruction of the colors and renovation of the façade is aimed at, among others, removing damages and dirt, restoring the original appearance (if possible) and securing the building against further damage. This work enables the preservation of historic buildings for future generations.

The analysis of the color of the tenement houses and their contemporary restoration includes buildings built in Wroclaw. Case studies are of a local nature. However, they can be seen in a broader social, cultural, and economic context. The restoration of the former color of tenement houses in Wroclaw requires comprehensive work to be carried out according to conservation requirements. This applies especially to many buildings that are still not renovated.

\subsection{Research Methods}

The article combines theoretical considerations on the history of tenement houses in Wroclaw, conservation research, and their practical application in the design and implementation of the renovation work of selected tenement houses. It is the result of literature studies (archival and contemporary materials) and iconographic research mainly concerning prewar materials collected in the Building Archive of the City of Wroclaw (Department of the Museum of Architecture).

These studies made it possible to compare the condition of an existing historical building with its archival project (and possibly with its initial appearance after construction). In many cases, they were also the basis for the reconstruction work and the reconstruction of damaged or missing elements and details of the façade. Archival projects were made with ink in a linear, black and white technique. Therefore, they were not helpful in recreating the original colors of the façade. Analytical studies of selected conservation techniques and the role of paint coating studies used in the renovation and shaping of the façade were also presented. The practical application of research methods was discussed on the basis of the author's five projects of renovation of Wroclaw tenement houses. The projects can be considered as the case studies in this article (Table 1).

\subsection{State of Research}

The contemporary state of research in the field of monument protection is very advanced. The issues of the color of the façades and interiors of historical buildings are less frequently discussed in available publications.

For example, a particularly valuable book, The Classical Orders of Architecture by Robert Chitham, is available in US and UK bookstores (Chitham 2005). It presents all classic 
architectural orders in a graphically accessible way. It can be helpful, for example, in the reconstruction of heavily damaged historical elevations.

Table 1. Structure of the article. Research methods and goals, thematic division, etc.

\begin{tabular}{|c|c|c|c|}
\hline \multicolumn{4}{|c|}{ Structure of the Article } \\
\hline Research methods & $\begin{array}{l}\text { Literature and iconographic } \\
\text { studies }\end{array}$ & Analytical research & Case study \\
\hline \multirow[b]{2}{*}{ Area of interest } & $\begin{array}{l}\text { State of research in the field of } \\
\text { colors of historical buildings }\end{array}$ & $\begin{array}{l}\text { Conservation studies of the } \\
\text { colors of historical elevations }\end{array}$ & $\begin{array}{l}\text { Renovation work with } \\
\text { conservation guidelines }\end{array}$ \\
\hline & $\begin{array}{c}\text { Stylish and color } \\
\text { transformations of tenement } \\
\text { houses in Wroclaw }\end{array}$ & $\begin{array}{l}\text { Methods of designing the } \\
\text { color concepts of historical } \\
\text { façades }\end{array}$ & $\begin{array}{l}\text { Application of scientific } \\
\text { studies to the design of } \\
\text { renovation work }\end{array}$ \\
\hline \multirow{2}{*}{$\begin{array}{l}\text { Research and practical } \\
\text { purposes }\end{array}$} & \multirow{2}{*}{$\begin{array}{l}\text { Obtaining and expanding } \\
\text { knowledge about the history, } \\
\text { technical condition of the } \\
\text { buildings and their elevations }\end{array}$} & $\begin{array}{l}\text { Improving the quality, scope, } \\
\text { and course of designing } \\
\text { renovation work }\end{array}$ & $\begin{array}{l}\text { Restoring the historical, } \\
\text { aesthetical and technical value } \\
\text { of façades }\end{array}$ \\
\hline & & $\begin{array}{l}\text { Obtaining and expanding } \\
\text { knowledge about the } \\
\text { conservation methods of } \\
\text { historical buildings }\end{array}$ & $\begin{array}{l}\text { Solving difficult and } \\
\text { controversial design and } \\
\text { construction problems }\end{array}$ \\
\hline
\end{tabular}

The publishing of books and manuals on architectural design and building trades has a very long tradition in Germany. Professional, often multi-volume manuals were printed even in the middle of the 19th century. However, few books dealt with the colors of façades or interiors.

The color shaping of old tenement houses from the 19th century has been discussed in two professional books: Fassadengestaltung mit Farbe, vom Entwurf bis zur Ausfürung by Georg Donauer, Heidrun Reusch, and Farbgestaltung historischer Fassaden in Wien by Friedmund Hueber (Donauer and Reusch 2007; Hueber 2008). The first book presents general information on the styles and colors of façades of residential and public buildings in Germany. The second is a kind of handbook for designing color concepts for restored tenement houses. Its author discussed the design principles using examples of Vienna's architecture, which can be used in other European cities.

It is important to analyze the many natural colors of building materials visible on nonplastered elevations. Some façades show visible surfaces and details made of traditional or glazed bricks, clinker, ceramic tiles, and various types of stone. Their manufacturing technology and colors were discussed in books even in the 19th century (Chabat 1880). At that time, in various countries, many catalogues and templates were published, presenting colorful drawings of plans and elevations of various residential and public buildings (Isabey 1867). These publications are now of great importance. They show old color suggestions for façades made with the use of various finishing materials.

Most books on color in architecture are published in English and German. Their subject matter concerns contemporary buildings and their color concepts. An important publication is The Anatomy of Color: The History of Heritage Paints and Pigments, in which the author presents the history of paints characteristic for various periods from 1650 to 1960 and their use in interior architecture (Baty 2017). Publications on interior colors constitute a separate group, often in the context of the psychology of vision, color perception, social, and cultural conditions. They are usually popular and informative in nature. Many of them are even bestsellers.

Many publications on conservation research appear in scientific journals or conference publications. A related topic appeared, for example, in articles such as case studies in stratigraphic studies of historical houses in Alentejo (southern Portugal), studies of color characteristics, and the conditions of using traditional lime painting technology (Gil et al. 2007, 2008, 2009). 
In Poland, scientific publications on the conservation of historical buildings are also published most often under the patronage of universities. They include, for example, scientific research and practical conservation activities and case studies (Kirschke and Kirschke 2017; Tomaszewski 1996). Their authors represent such professions as conservators, academic researchers and authors of conservation projects.

\subsection{International Importance of Research and Conservation Work in Wroclaw}

Documents adopted at the level of the European Union and individual member states show attention to the larger social context of monuments and cultural heritage protection. The national regulations are in line with EU law.

Article 6 of the Treaty on the Functioning of the European Union (TFEU-the main act of primary law of the European Union) is of great importance for the protection of cultural heritage. It lists a wide range of activities, including education, research, and the protection of the cultural heritage (EU Strategy 2021).

Experiences in the design and implementation of conservation work in Wroclaw can be considered as model processes of the restoration and maintenance of the good condition of historical buildings. They lead to the improvement of the technical condition of tenement houses and represent the highest standard in the field of conservation knowledge and construction techniques. They are implemented as part of the protection of architectural heritage with the financial support of the Polish government and European Union funds. They can be an example for conservation initiatives in other Polish cities and even in other neighboring European cities.

\section{Tenement Houses in Wroclaw in the 19th and Early 20th Century and Their Colors}

\subsection{Tenement Houses in Wroclaw}

In the 19th century, the "tenement house" was a common space for people with different incomes and social status to live (Domińczak and Zaguła 2016). Houses with more representative features (richly decorated elevations, large apartments, etc.) were inhabited by owners and tenants with a high financial status. These buildings were on the street. They formed quarters of external buildings between the streets crossed. Inside the quarters, modest outbuildings of a lower standard were built with small apartments. They were rented to many people with a poor financial status (Klasen 1889; Tomaszewicz 2003). The tenement houses in Wroclaw were distinguished by their scale. They were usually very tall. They even had five upper floors (six together with the attic) and a basement (Figure 1).

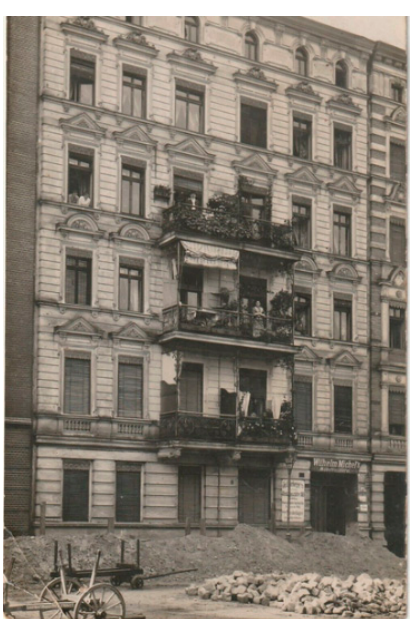

(a)

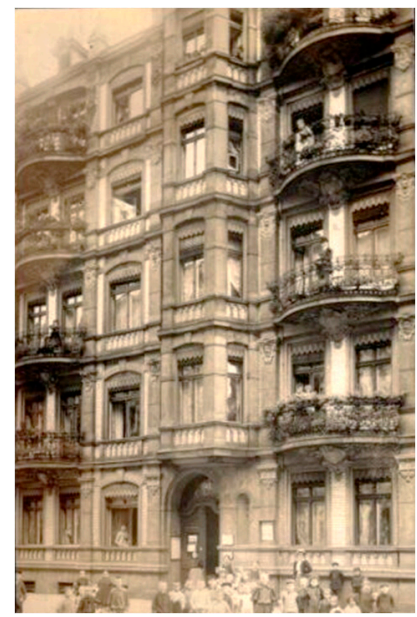

(b)

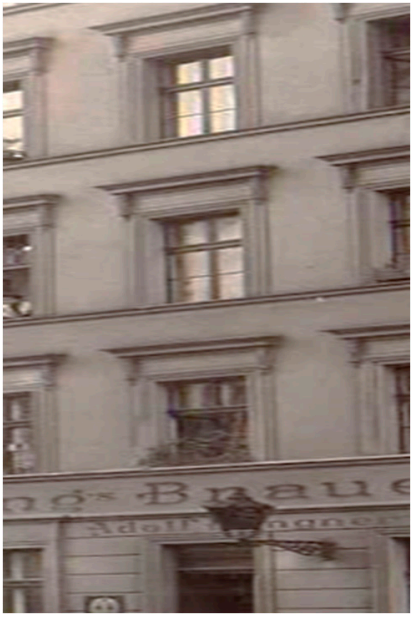

(c)

Figure 1. Wroclaw tenement houses, 5-6 floors high, shown on postcards from 1907-1911 (a-c). 
Currently, tenement houses are usually inhabited by people with similar financial and social status. Many apartments are owned by users, some are rented, and others have various nonresidential functions, for example, an office function. Diversified ownership status within one building often makes it difficult to carry out renovation work and apply for renovation financial subsidies.

\subsection{The Style and Color of Tenement Houses from the 19th and Beginning of the 20th Century}

Most of the preserved buildings in Wroclaw date from the second half of the 19th and the beginning of the 20th century. Tenement houses were built mainly in eclectic, historical Neo-Renaissance style, and later in the Art Nouveau style (Figure 2). Other styles, such as Neo-Romanism, Neo-Gothic, and Tudor, were rarely represented. These styles corresponded to the aesthetic trends in architecture at that time. They are still clearly visible on preserved objects. Tenement houses were usually richly decorated. The ornaments were modeled on old architecture and art eras and styles. The decorations of some tenement houses even represented an eclectic combination of several styles. The eclectic style did not lead to the creation of new stylish forms of synthetic quality. The combined decorative elements and colors were not subject to constant selection criteria. They did not create a homogeneous whole in terms of style and color. This stylish solution is represented, that is, by the renovation project of the tenement house on Krasinskiego St. 21-23, Wroclaw (2015).

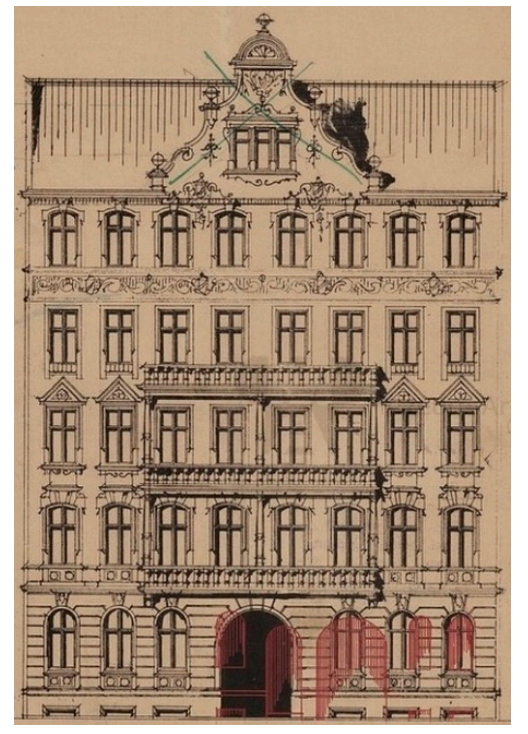

(a)

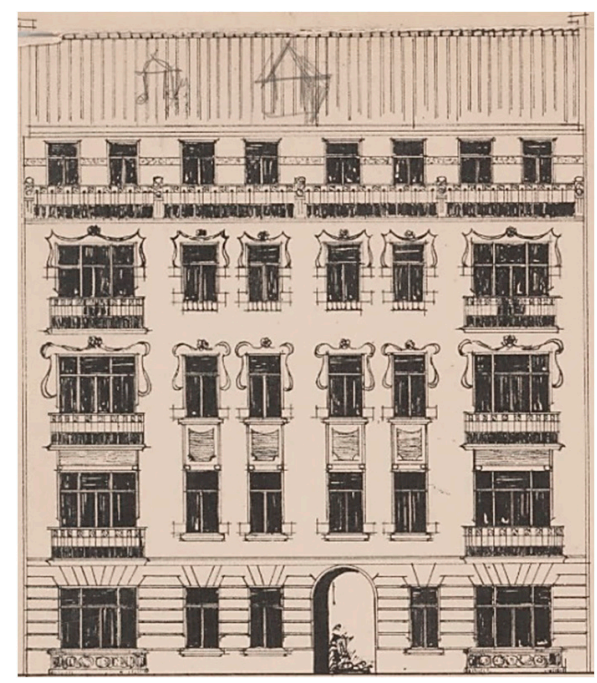

(b)

Figure 2. Archival façade projects of tenement houses in Wroclaw in the Neo-Renaissance (a) and Art Nouveau (b) styles (Collection of the Building Archive of the City of Wroclaw).

Mass construction of richly decorated tenement houses was made possible thanks to widespread catalogues, templates, and diagrams, and even prefabricated architectural details, plaster models, etc. (Figure 3) (Donauer and Reusch 2007). It seems that not only was mass-colored plaster used at that time, but also the technique of painting was used. Painting the façade surface was a simpler and cheaper construction technique.

Tenement houses in the historical neo-style (Neo-Renaissance, Neo-Romanism, NeoGothic) gained expressive colors in the 1830-1850s. The colors were more saturated compared to the previous neoclassical style. Strong saturation and color contrast were perceived as synonyms of strength and power, and less saturation as synonyms of weakness and delicacy (Figure 4a) (Donauer and Reusch 2007). This convention is represented, that is, by the renovation project of the tenement house on Kniaziewicza St. 17 (2017). 


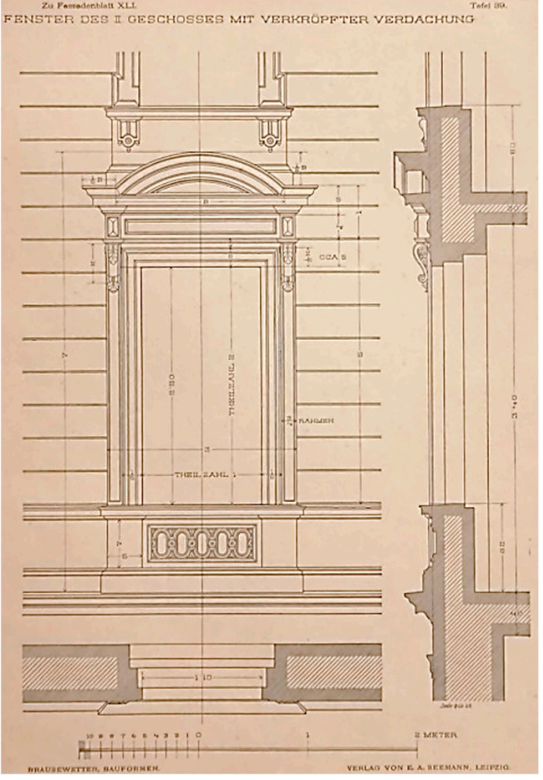

(a)

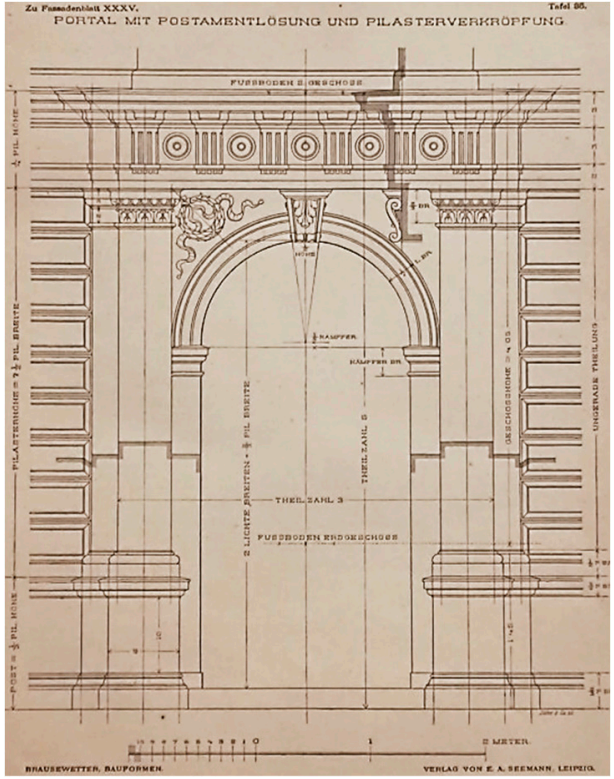

(b)

Figure 3. Archival boards of Neo-Renaissance architectural details. Details of window trim (a) and entrance door portal (b) (Brausewetter 1898).

(a)

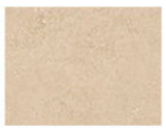

(b)

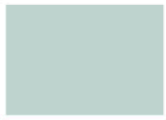

(c)

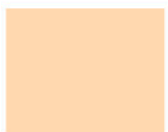

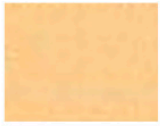
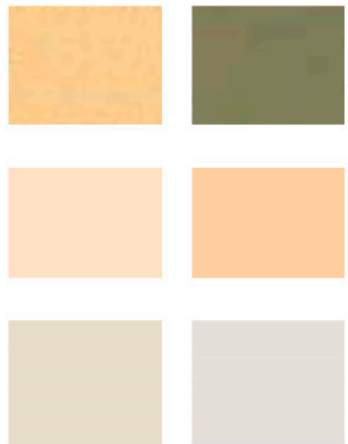
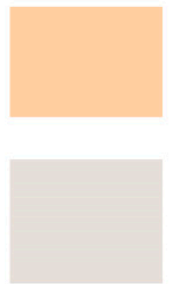
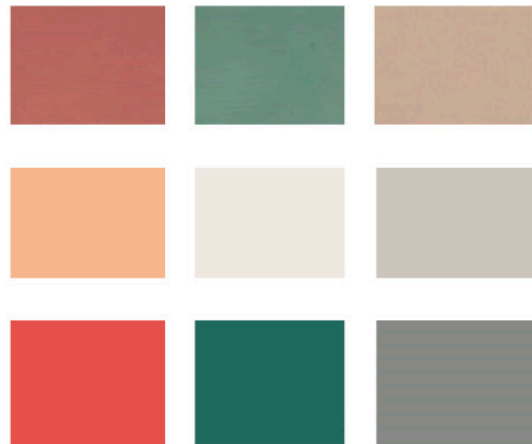

Figure 4. Examples of intensive (a) and bright (b) colors in the style of Historicism and Art Nouveau (c). Inspiration (Donauer and Reusch 2007).

From the middle of the 19th century, the façade colors were less saturated and less expressive (Figure 4b) (Donauer and Reusch 2007). The surfaces of the walls, the tectonic divisions, and the details were more often of homogeneous color. This convention is represented, that is, by the renovation project of the tenement house on Podwale St. 61 (2014).

Most of the Wroclaw tenement houses had plastered elevations. Profiles (cornices and window trims), rustication, and ornaments were also plastered. Brick elevations were also implemented. The bricks were fired in a natural red or ocher color. More decorative glazed bricks, for example in dark green, were also used. The color palette of these façades represents the natural colors of the earth (the material color of the fired bricks). This convention is represented by the renovation project of the tenement house on Grabiszynska St. 101 (2014).

At the turn of the 19th and 20th centuries, in the Art Nouveau period, the colors of the façade gained more saturated tones again. It was a reaction to the dirty and faded colors of older buildings (Donauer and Reusch 2007). At that time, colors such as dark blue, dark green, purple, red, gold, etc., were very popular (Figure 4c). These colors were usually combined with pastel shades on large surfaces. This convention is represented, for example, by the renovation project of the tenement house on Kosciuszki St. 37, Wroclaw (2015). 
At the beginning of the twentieth century, the color diversity of Wroclaw architecture was perceived as unique compared to the other German cities (Urbanik 2019a). This is evidenced by the statement by Adolf Rothenberg of the State Academy of Arts and Crafts in the journal Ostdeutsche Bauzeitung Breslau. He wrote: "Our city is currently marching at the forefront of Germany when it comes to shaping streets and squares in color" (1927) (Rothenberg 1927). The text was concerned not only with the modernist architecture of that time, but also with older buildings from the 19th and early 20th centuries (Urbanik $2019 b$ ). It can be assumed that the different colors of the tenement houses resulted from the widespread use of painted, plastered surfaces of the façades, which could easily be given any color. The natural colors of the building material are noticeable on brick, clinker and stone elevations.

The bold color propositions of the old elevations are represented, for example, by a tenement house in its original state in the Art Nouveau style on Rozbrat St. 12. It has not been revitalized so far. The combination of dark red and gray colors, tectonic divisions, varied plastering structures and beautiful stucco is impressive (Figure 5).

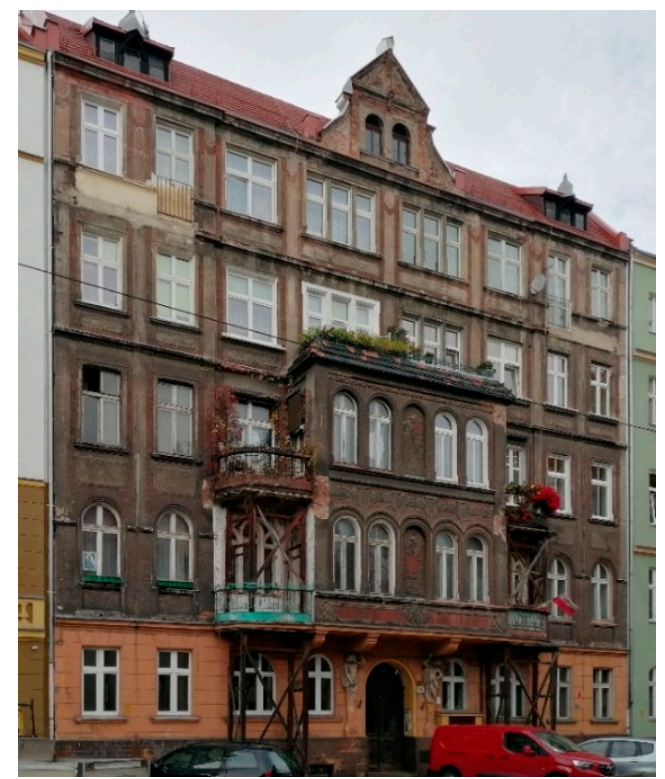

(a)

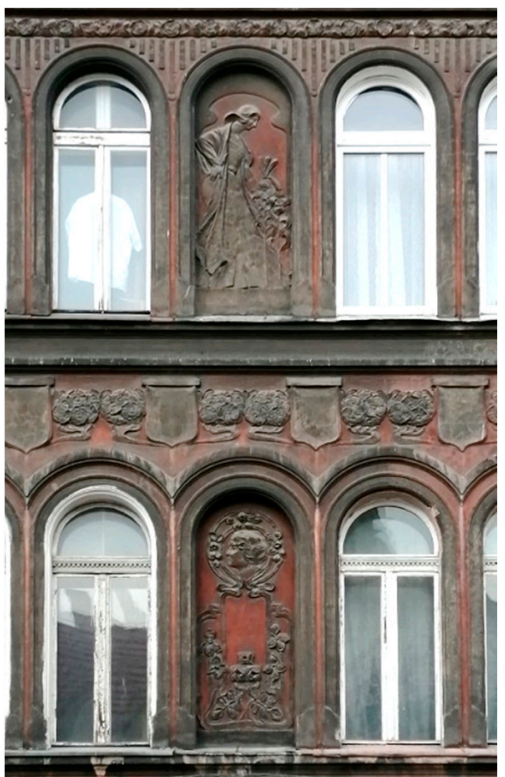

(b)

Figure 5. A tenement house in the Art Nouveau style on Rozbrat St. 12 (a). Dark red and gray colors and stucco $(\mathbf{b})$.

\section{Rebuilding and Preservation of Tenement Houses in Wroclaw after 1945}

Unfortunately, Wroclaw was badly damaged during World War II. The most valuable historical buildings (mainly churches, the center of Wroclaw's Old Town and some public buildings) were rebuilt in the first postwar years (Thum 2005). Tenement houses were of less historical importance. That is why they were rebuilt for several years. At the same time, a significant portion of the buildings, damaged during the war, were demolished.

After 1945, façade colors were rarely studied. From the mid-1990s, conservation research became an integral part of the restoration process (Białobłocka 2014). Since then, conservation offices have increasingly required this research. Its goal is to preserve or restore the original (first historical) appearance and architectural style of old building. It is important to preserve the traces of the original condition, despite the damage and later layers of plaster and paint.

In recent years, municipal authorities have financially supported monument owners in the field of reconstruction, renovation, and protection against destruction. Among other things, in 2006, a large program of renovation of tenement houses was started"100 tenement houses". From 2009, restoration programs were used as the basis for applying 
for EU subsidies (Eysymontt et al. 2011). Their goal was to improve the condition of historical buildings and the quality of life of the inhabitants. Furthermore, it was important to improve the cultural values of the renovated tenement houses.

\section{Conservation Research before Design and Renovation Work}

The entire investment process that leads to the renovation of the tenement house is a multistage process. The design study contractor should collect as much information as possible about the historical and current condition of the building (i.e., iconographic archival material). The old projects of many tenement houses are available in the Building Archive of the City of Wroclaw.

\subsection{Information Prior to Design Work}

Archival design documentation usually includes the most important project plans. Façade drawings are often different from those of the existing building. Design concepts were probably changed already at the construction stage, under the influence of new aesthetic trends in architecture (Historicism styles vs. Art Nouveau or Modernism), or the houses were later rebuilt. In this case, the archival documentation must be verified. On the other hand, archival drawings and plans that match the current appearance of the building are used to prepare an inventory and even a graphic part of the final project.

On-site research of tenement houses shows different states of preservation of historical colors (Białobłocka 2014). The original color scheme is visible on the unchanged building. The partial and mixed color scheme occurs mainly in the reconstructed buildings. The oldest form may no longer exist. Restoration of the colors can be controversial. The final color scheme can be a combination of primary and new colors. Other factors that influence the choice of colors may be the properties and price of the paint or the attempt to match the building to its urban surroundings.

Color perception and color shaping of space are subjective phenomena (Donauer and Reusch 2007). The traces of the original appearance and colors of the building are of scientific and objective importance. Decisions about façade colors are made by participants in the renovation process: the architect, monument conservator or investor, renovation company (carrying out the investment), and paint producers. Research studies, realized, e.g., by historians of architecture and art, are of great importance. In Wroclaw, they usually precede the restoration work of buildings of exceptional historical or aesthetical value.

\subsection{The Role of Stratigraphic Studies}

The Wroclaw Municipal Monuments Conservator Office requires the façades of the renovated buildings to be restored to their original condition. This applies, in particular, to the objects entered in the Monuments Register. Fulfillment of this is a condition for issuing a conservation permit and a permit to carry out renovation work. Official approval of the preservation program is also part of the subsidy application.

When the technical condition of the upper layers of wall painting is examined, the stratigraphy technique is used. Its purpose is to determine the order of occurrence of the material layers of the façade (Stratigraphic Studies 2021). Traces of paint layers from the period when the building was erected are considered "authentic", "original" (Święcka 2017).

The colors revealed on the walls of the stratigraphic outcrops usually no longer have the original saturation (intensity). They are faded and dirty. Determining primary colors often requires chemical analysis of pigments, microscopic observation of samples, and other detailed studies.

According to some researchers, the original state of the object does not always have the highest artistic value and is often poorly preserved. Conservation decisions require knowledge of the entire structure of the building. Therefore, appropriate architectural studies are applied, including subsequent transformations. Sometimes, the oldest traces of 
color can only be discovered in the newer, added part of the building. Its oldest part may be devoid of the earliest traces of color (Tomaszewski 1996).

\subsection{The Course of Stratigraphic Work}

The subject of stratigraphic studies are often large areas of multi-floor elevations. The work on large elevation surfaces is sometimes carried out by teams of several specialists. They make outcrops in many places of the façade. They take samples on smooth walls, plinths, cornices, corners, window and door recesses, architectural details, etc. Access to the fragments located above requires high scaffolding or the use of a basket lift on a truck.

\section{Design of Color Concepts}

Designing and implementing the color concept of an old building is part of a complex investment process. The success of the project and the achievement of a high historical and technical quality of the building requires a wide knowledge of old construction techniques and modern technologies to design and perform construction work.

\subsection{Identification of Historical Colors}

Stratigraphic studies should allow for the discovery of all colors and the arrangement of their distribution on the façades of the building. The samples obtained usually show colors with distorted characteristics (tone, saturation, cleanliness) (Zeugner 1965). After decades, paint colors are damaged by various harmful influences. The following damage occurs:

- changes in color tone as a result of chemical and biological changes in the structure of the coating, e.g., chemical and biological corrosion;

- changes in color saturation due to fading (lightening and yellowing), e.g., during UV radiation;

- changes in color cleanliness as a result of dirt, dust, etc.

\subsection{Recreating the Color Palette}

Changing the characteristics of historical colors often requires laboratory tests to restore their tone, saturation, and cleanliness.

In the façade color design, the colors and their features should be precisely defined. Appropriate templates are helpful here. The first templates and color recommendations for the elevation were published at the end of the 18th century (Figure 6a) (Wojtysiak 2003). Currently, you can precisely choose any façade colors according to their numbers. The universal NCS-Natural Color System - template is often used (Figure 6b). The paint manufacturer's color template offers a more precise selection of colors. The colors of varnish coatings are most often selected in the RAL system (painting, for example, of metal or wooden elements). Computer design of colored objects is possible thanks to the RGB system, which enables additive mixing of primary colors, red, yellow, blue, and black (Donauer and Reusch 2007).

Today, many manufacturers offer various products for façade renovation. Some paints are based on zinc- or titanium-white. They have a negative impact on the monuments in terms of color hue (the color palette does not match the original samples) and chemical structure (they react negatively with the historical substrate) (Wojtysiak 2003). Architecture conservators prefer lime-based renovation products and historical color palettes, for example, those by the "Keim" and "Caparol" producers (Wandrychowska 2014; Witkowska 2015b). 


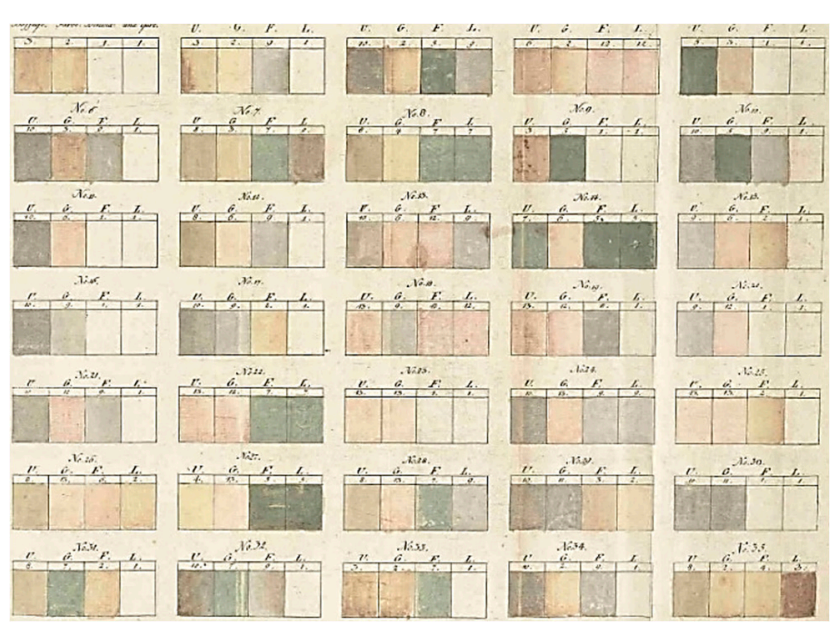

(a)

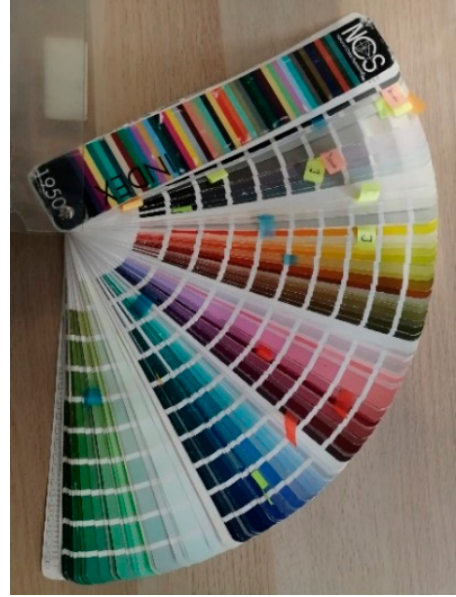

(b)

Figure 6. The façade color pattern made by F. Ch. Schmidt in Der bürgerliche Baumeister, 1790 (Wojtysiak 2003) (a). The modern color template, NCS-System (b).

\section{Examples of Color Design for Historical Tenement Houses in Wroclaw}

In this article, the author has presented fragments of his own projects made for the "Archimmodicus" Design Studio, in cooperation with Dorota Wandrychowska's Conservation Studio and Anna Witkowska's Conservation Studio. The scope of the projects concerns the proposed material and color solutions, as well as design decisions in cooperation with the Wroclaw Municipal Monuments Conservator Office. There are presented projects for the renovation of five tenement houses, built in different periods and styles. The houses are located in Wroclaw on Krasinskiego St. 21-23, Kniaziewicza St. 17, Podwale St. 61, Grabiszynska St. 101, Kosciuszki St. 37.

\subsection{The Tenement House, Krasinskiego St. 21-23, Wroclaw}

The building was erected in 1899 (Eysymontt et al. 2011). The wide front façade has very distinct tectonic divisions in the Neo-Gothic and Tudor styles (Nowakowski 2015a; Eysymontt et al. 2011). Smaller details with plant and allegorical motifs are in the Neo-Baroque style. This building represents the eclectic trend in Wroclaw architecture.

The design work was preceded by research to obtain knowledge of the renovated building and its façade. Literature studies made it possible to find the date of construction and the earliest fate of the house. Careful iconographic research was carried out in the Building Archive of the City of Wroclaw. The historical documentation revealed floor plans and drawings of the elevation that matched the actual appearance of the building. They were used to develop an inventory plan and fragments of the final project. An analysis of the façade archival drawings revealed proposals for numerous sculptural decorations. The renovation required reconstruction and repair of many stucco details in the Neo-Gothic and Tudor styles (Eysymontt et al. 2011). For this, additional studies of medieval and Neo-Gothic architecture and art were necessary (Gründling 1998; Opderbecke and Issel 2001). The research was the basis for the design of the missing elements. The historical documentation was drawn quite schematically, on a small scale.

On-site research showed different states of preservation of the elevation (Figure 7). They were included in the inventory plan. The plan was useful in determining the scope and costs of the renovation work. 


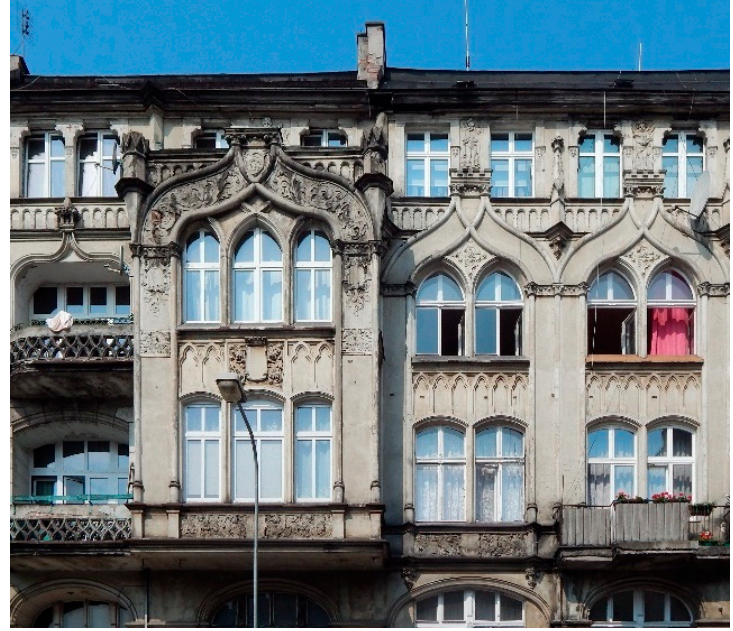

(a)

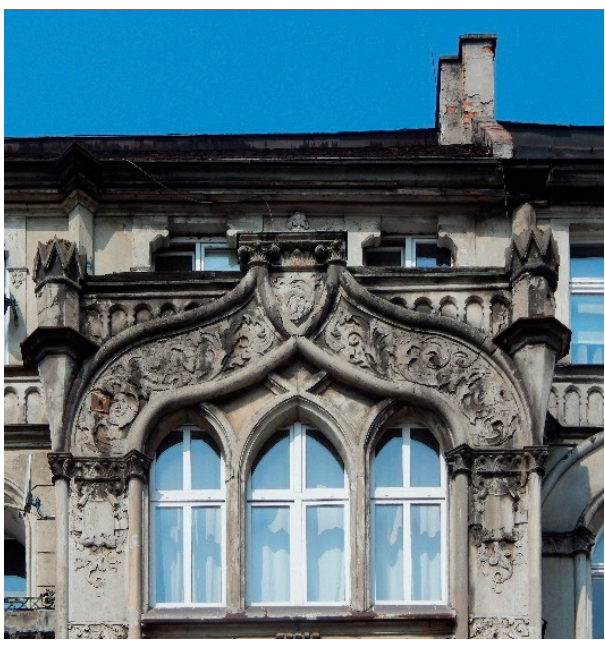

(b)

Figure 7. Tenement house, Krasinskiego St. 21-23, Wroclaw. Elevation before renovation work (a). Architectural details were missing on the terrace balustrade (b).

The stratigraphic studies showed the existence of the original paint coating on the walls and the stucco details. The façade color was compared with the color palette in the "NCS" system: "S1515-Y20R" or "S1010-Y20R" (Witkowska 2015a). A slightly cooler color tone, "S1510-Y30R" or "1515-Y30R", was also allowed. Finally, the architect chose the beige color of the façade according to the "NCS S1010-Y20R" system. He also used the brown color of the steel balustrades and the aforementioned windows, doors, and shop windows, "RAL 8015" (Nowakowski 2015a). The renovation work was carried out by a renovation company according to the conservation recommendations, as well as the construction and detailed project (Figure 8).

\subsection{The Tenement House, Kniaziewicza St. 17, Wroclaw}

The building was erected about 1850 . The front elevation has very distinct tectonic divisions with pilasters and cornices. The first two floors are rustic. The decoration is complemented by cast sculptural plaques, such as garlands, consoles, and symbolic and allegorical compositions. The plaques are rectangular or semicircular in shape.

Careful iconographic research was carried out in the Building Archive of the City of Wroclaw. The documentation revealed floor plans and drawings of the façades that matched the actual appearance of the building. However, the elevations were sketchy in shape, and the architectural details were shown schematically. They were used to develop an inventory plan and fragments of the final project. Drawing the preserved details and stucco plaques in the project required careful photographic documentation. It was also the basis for the design of the missing decorations. They were also designed on the basis of the existing elements. The research on site showed that the façade was in good condition (Figure 9). It was included in the inventory plan. It was also the basis for determining the scope and costs of the renovation work.

The stratigraphic study showed the existence of a primary layer of stucco decoration and elevation painting. They were made within the flat surfaces of the walls, on some sculptural plaques, cornices and pilasters. The colors were compared with the "Caparol 3Dplus" pattern (Nowakowski 2017; Witkowska 2017). Finally, the architect proposed façade colors in cool green shades, according to "Caparol 3Dplus" - "Moos 50", "Patina 70" as a renovation paint system, and the brown color of the woodwork "RAL 8024" (Figure 10). 
(a)

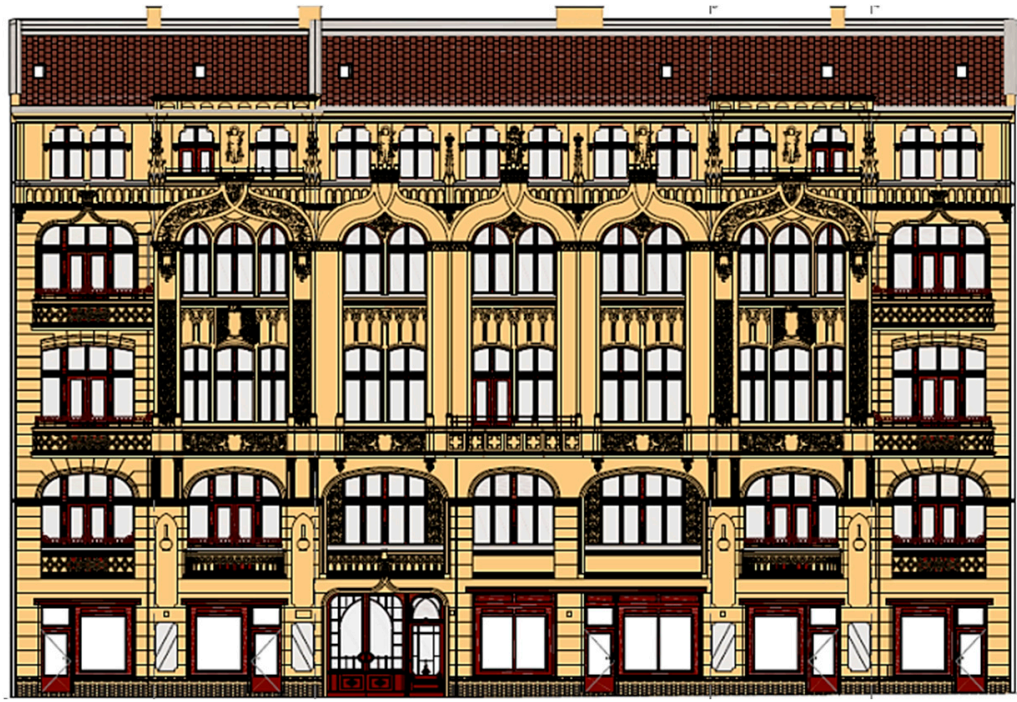

(b)

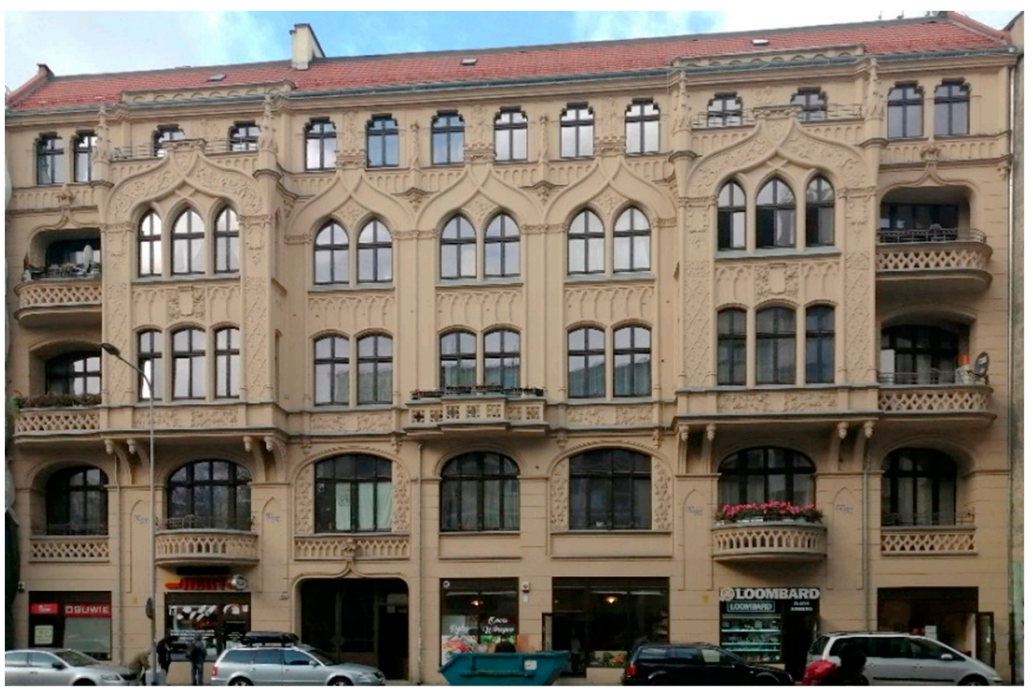

Figure 8. Tenement house, Krasinskiego St. 21-23, Wroclaw. Design of the colors of the front elevation (a) and the elevation after renovation (b) (Nowakowski 2015a).

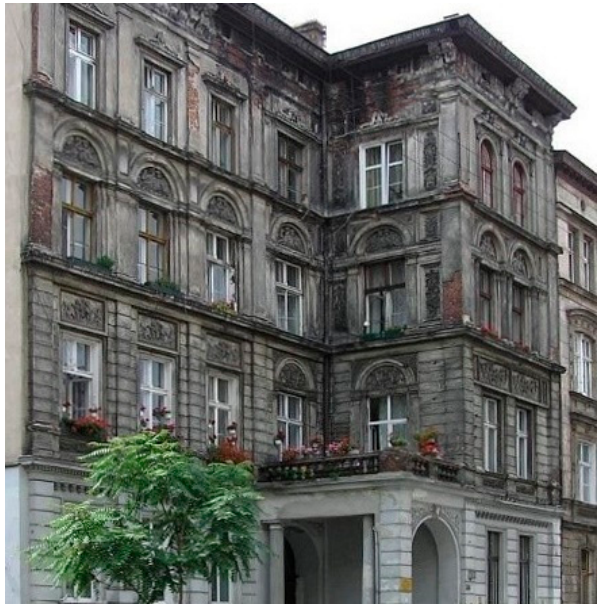

(a)

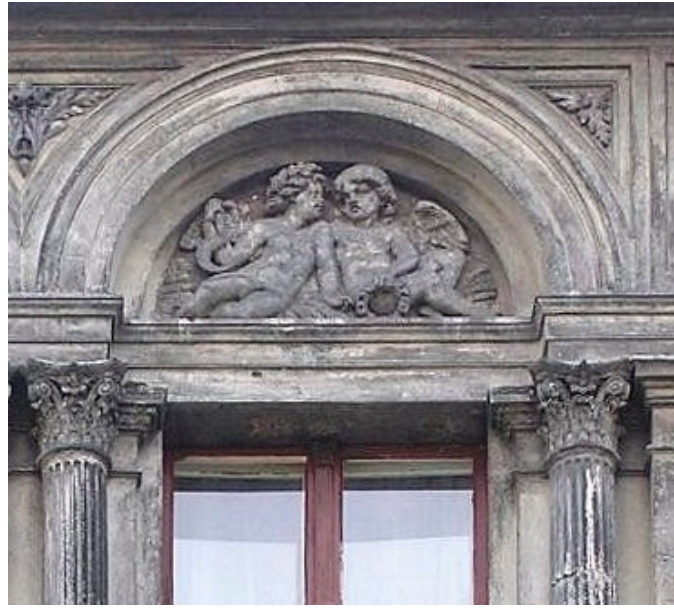

(b)

Figure 9. Tenement house, Kniaziewicza St. 17, Wroclaw. Elevation before renovation work (a), Preserved stucco details, cornices, columns and pilasters with peeled paint $(\mathbf{b})$. 


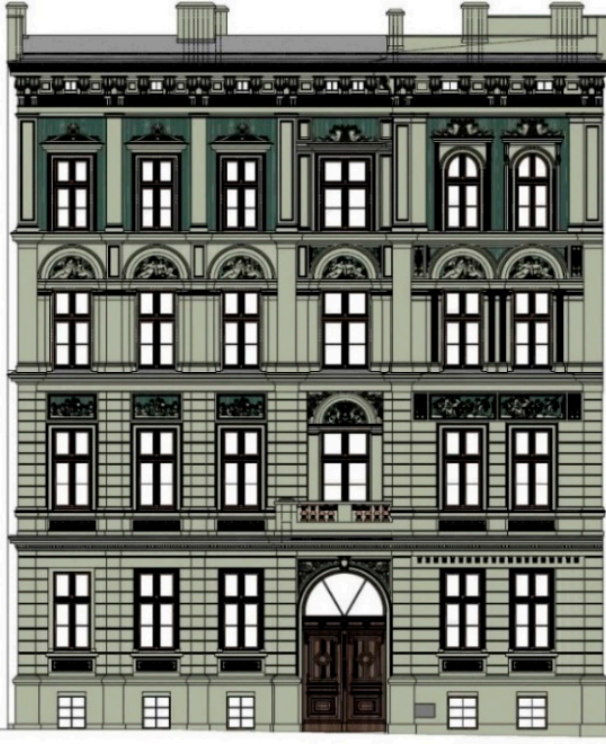

(a)

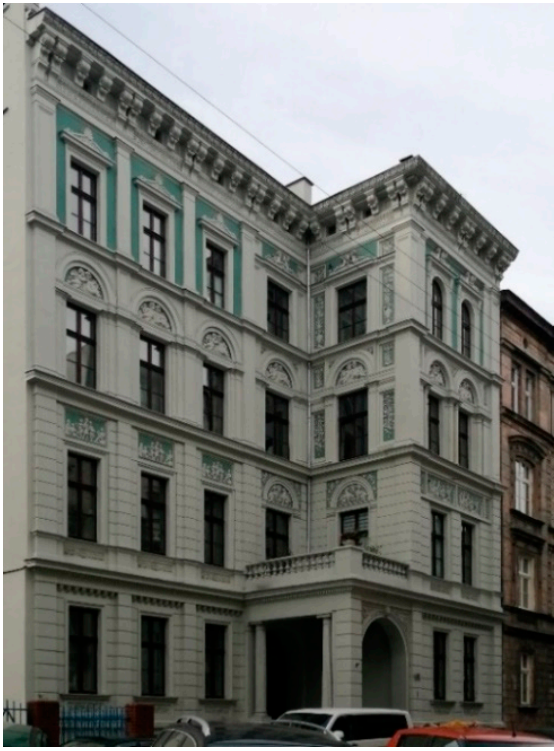

(b)

Figure 10. Tenement house, Kniaziewicza St. 17, Wroclaw. Design of the front elevation colors (a) and the front elevation after renovation (b) (Nowakowski 2017).

The scope of the renovation work also included the renovation of the internal staircase. The renovated interior doors were painted in RAL color and glazed with non-transparent window panes (Figure 11).

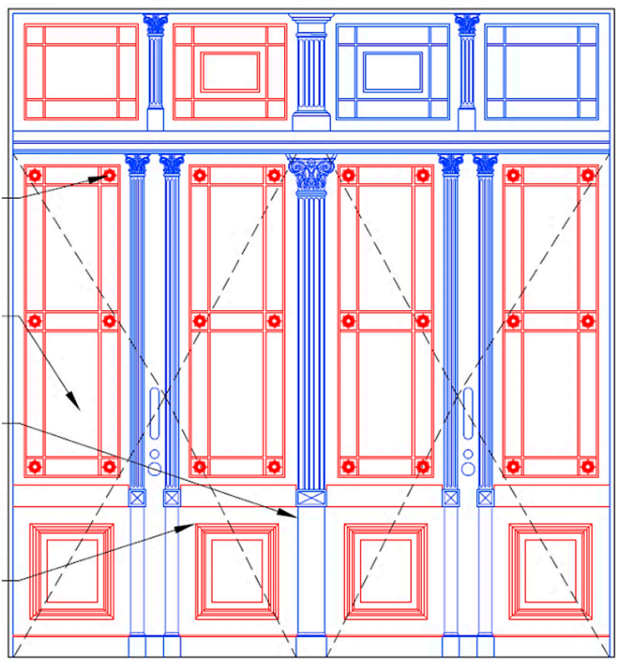

(a)

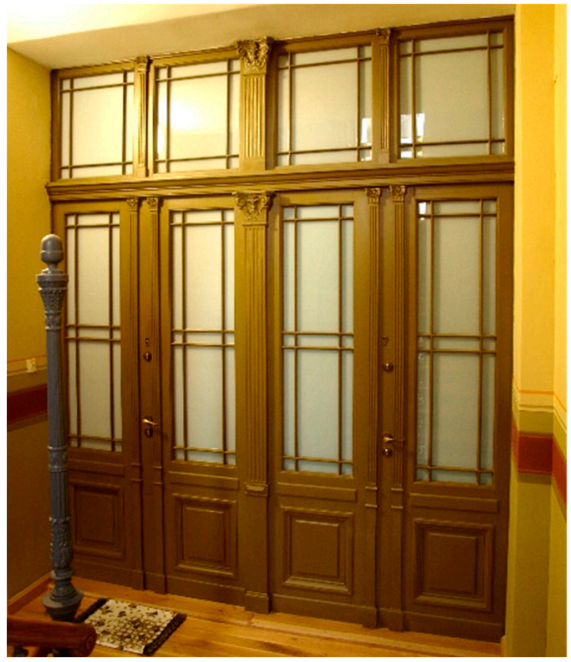

(b)

Figure 11. Historical door project. Reused historical woodwork is shown in blue (a) (Nowakowski 2017). The doors after the renovation work (b).

The stratigraphic research showed a very decorative painting of the walls of the staircase (Figure 12a). The outcrop has revealed a relatively good condition of a fragment of the original painting. There were four painting conventions used:

- $\quad$ painting covering large surfaces of walls with a wide brush in earthy, green, and maroon colors;

- painting a few stripes with a narrow brush in intense earthy colors;

- painting the ribbed decoration in blue-green with a roller;

- template painting with floral decoration in a lighter blue-green color. 


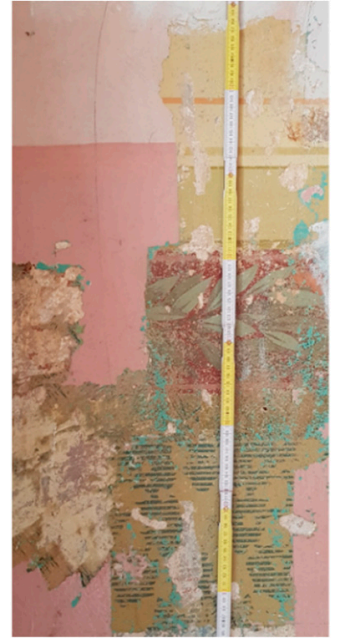

(a)

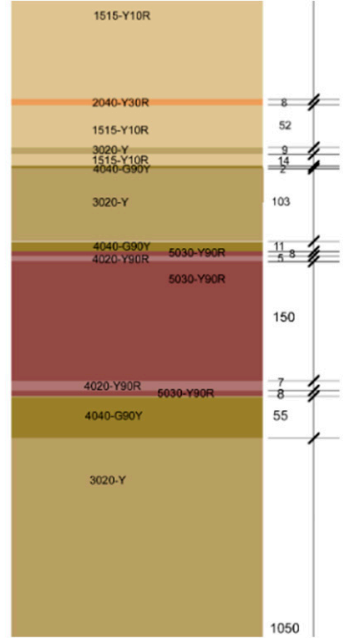

(b)

Figure 12. Exposure of the fragment of the original staircase painting and pattern (a) and a simplified reconstruction project (b) (Nowakowski 2017).

However, the walls of the staircase were later repainted in a pink shape. Oil and emulsion paints were used at that time (Figure 12a).

Reconstruction of the original look of the staircase turned out to be too expensive for the renovation budget. The application for co-financing was submitted before the stratigraphic study. The architect designed a simplified color scheme in agreement with the Wroclaw Municipal Monuments Conservator Office (Figure 12b). He also decided to protect the uncovered fragment of the original pattern (Figure 13a). The new, controversial concept included the design of general divisions with colored stripes, parallel to the stairs. "Caparol" colors in earthy shades (including ocher and olive green) and burgundy were used, according to the NCS system (Figure 13b).

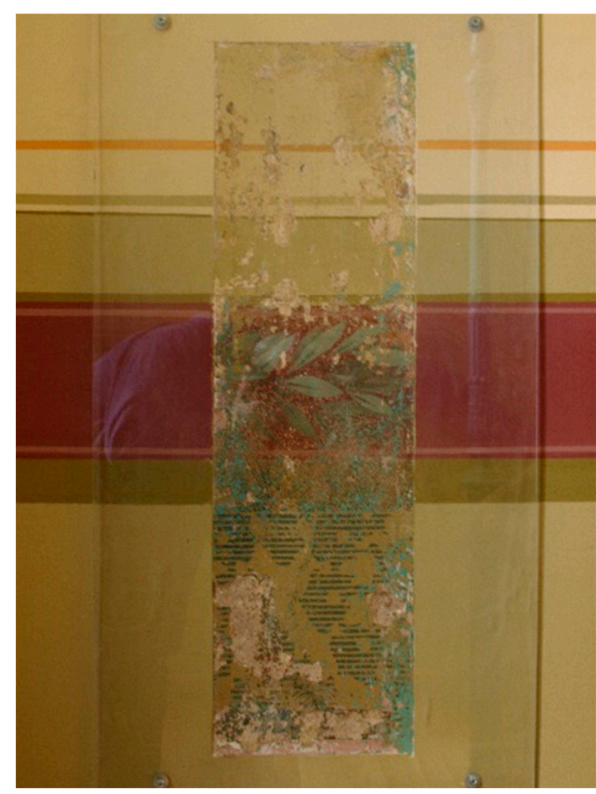

(a)

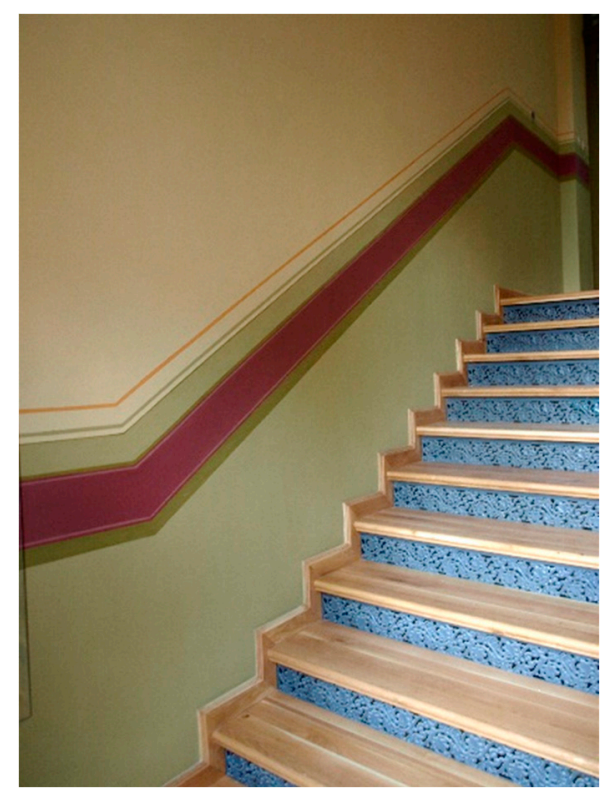

(b)

Figure 13. Securing the original fragment behind a glass pane (a). Reconstruction of the wall painting of the staircase after the renovation (b). 


\subsection{The Tenement House, Podwale St. 61, Wroclaw}

The house was erected in 1846 (Eysymontt et al. 2011). The front elevation is decorated in a Gothic-inspired style. The styling is particularly visible as a rustication of the walls, sharp arches of window lintels and gates (Tudor style), and a characteristic battlement with turrets (Eysymontt et al. 2011). The façades are almost entirely covered with lime plaster. Most of the architectural details are also plastered. Other materials and details were also used: zincal balcony balustrades (zinc and aluminum alloy-ZnAl), gate frame and turrets made of sandstone, and a granite plinth.

Literature studies made it possible to find out when the house was built (Eysymontt et al. 2011; Wandrychowska 2014). The design work was preceded, among others, by iconographic research in the Building Archive of the City of Wroclaw. The historical documentation revealed floor plans, and the elevation drawings partially match the actual appearance of the building. An analysis of the archival drawings showed proposals for numerous sculptural decorations. However, they were different from the preserved architectural details (e.g., battlements with turrets). The renovation required the recreation and repair of many details (Figure 14). For this purpose, additional studies of Gothic architecture and art were necessary, especially in the Tudor style (Gründling 1998; Opderbecke and Issel 2001). They were the basis for the design of the missing elements. The archival documentation was drawn quite schematically, on a small scale. Old photos, showing, for example, balconies on the 3rd floor that no longer exist, turned out to be more reliable. Research in the additional literature and consultation with the manufacturer required the design of new windows. They were to have a distinct, historical appearance. They also had to meet modern requirements, e.g., in terms of durability and thermal insulation.

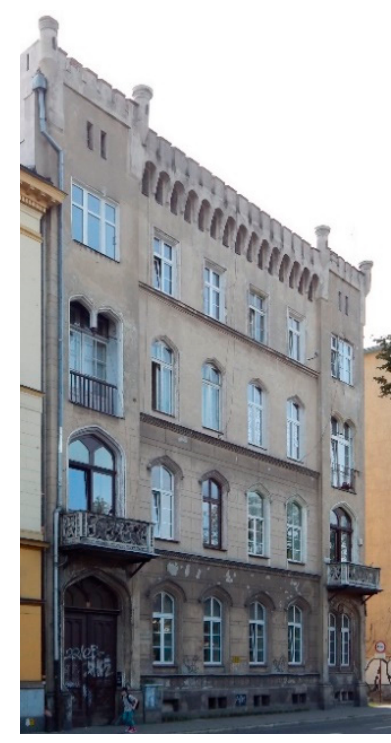

(a)

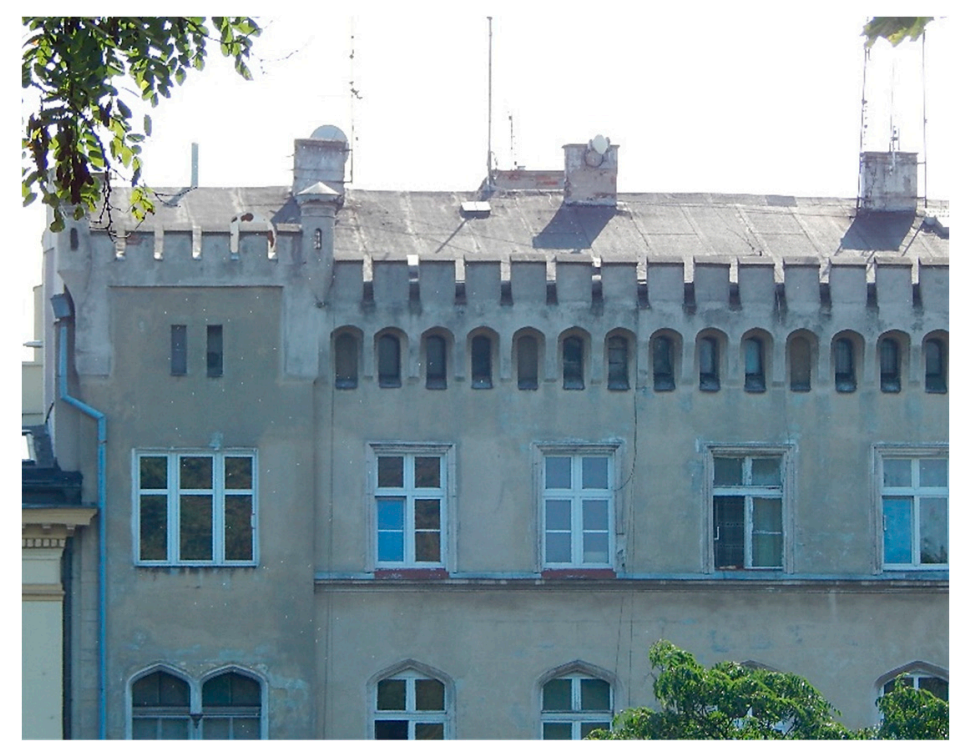

(b)

Figure 14. The tenement house, Podwale St. 61, Wroclaw. Dirty elevation with peeling paint. There were no balconies on the third floor (a). Characteristic battlement with peeled paint. Details of the turrets were missing (b).

Stratigraphic studies showed the existence of the primal paint layer in an earthy hue (referring to the natural building material) (Wandrychowska 2014). The original color was similar to "Caparol Histolith Dunkler Ocker 20". As a result of stratigraphic studies, comprehensive conservation work was recommended on the surfaces of flat walls, plaster and sandstone, architectural details, door and window joinery, and metal details (Figure 15a) (Nowakowski 2014b; Wandrychowska 2014). The ocher color was proposed on the elevation according to the "Caparol Histolith System, Dunkler Ocker 20" (Figure 15b). 
The original color of the windows could not be determined. The gray color of the windows (RAL 7040) was established after consultation swith the Monuments Conservator Office. The decision was made based on the experience gained after the renovation of other tenement houses in Wroclaw, built in a similar period.

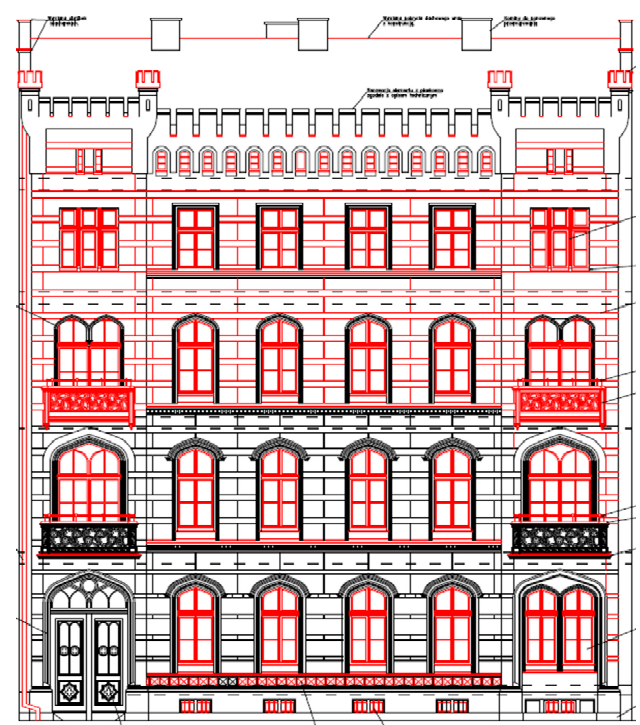

(a)

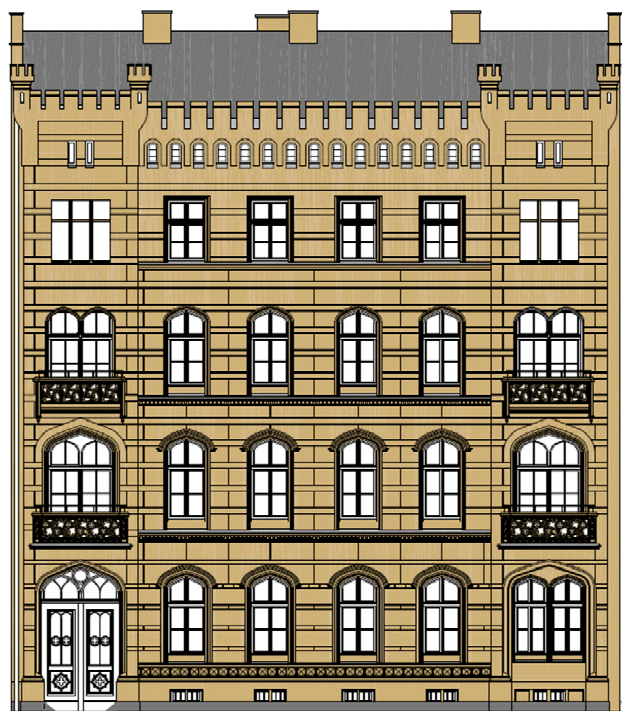

(b)

Figure 15. The tenement house, Podwale St. 61, Wroclaw. The graphical scope of the renovation, marked in red (a) and the color concept of the front elevation (b) (Nowakowski 2014b).

The balconies on the second floor were made of zincal segments joined with rivets. They were placed on a brick balustrade. The third-floor balconies were completely reconstructed with similar technology.

The preservation work was carried out according to conservation recommendations, as well as the construction and detailed project (Figure 16).

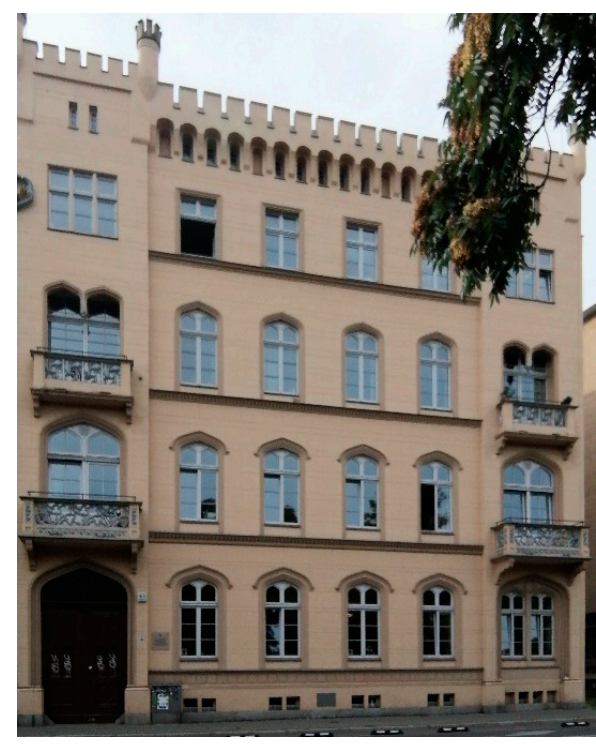

(a)

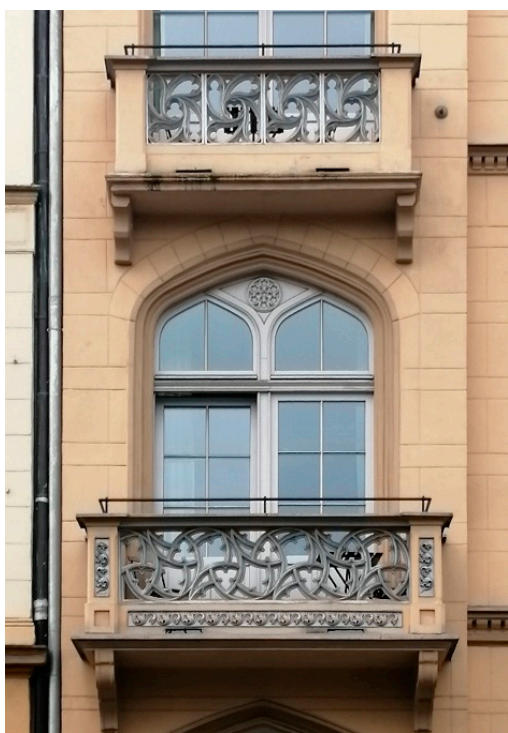

(b)

Figure 16. Front elevation colors after renovation (a). Reconstructed zincal balcony balustrade details with Gothic motifs and replaced windows (b). 


\subsection{The Tenement House, Grabiszynska St. 101, Wroclaw}

The building was erected around 1890. The front façade was made in the NeoRenaissance style. The walls have an exposed arrangement of ocher bricks (Nowakowski 2014a). The oriel, cornices, window trims, etc., are plastered. This building represents the trend of colors of natural materials in the architecture of Wroclaw.

Research in the Building Archive of the City of Wroclaw revealed the lack of archival documentation. However, the renovation work required the reconstruction and repair of many stucco details (Figure 17). Additional studies of Renaissance architecture were necessary. Useful publications were: Das Bauformenbuch. Die Bauformen des Bürgerlichen Wohnhauses by Artur Brausewetter and The Classical Orders of Architecture by Robert Chitham (Brausewetter 1898; Chitham 2005). They were the basis for the design of the missing stucco elements. The design study was carried out in 2014. At that time, this house was not listed on the Monuments Register. The stratigraphic studies were not required by the Municipal Monuments Conservator Office. As part of the investigation on site, the architect discovered fragments of the original colors of the plastered façade fragments. Damage to the plastered surfaces (revealing hidden paint layers) proved to be helpful in the research.

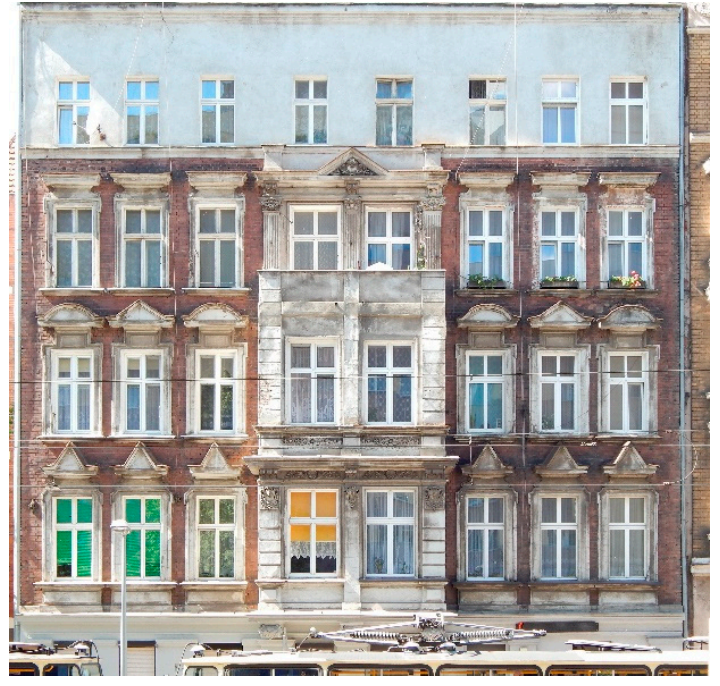

(a)

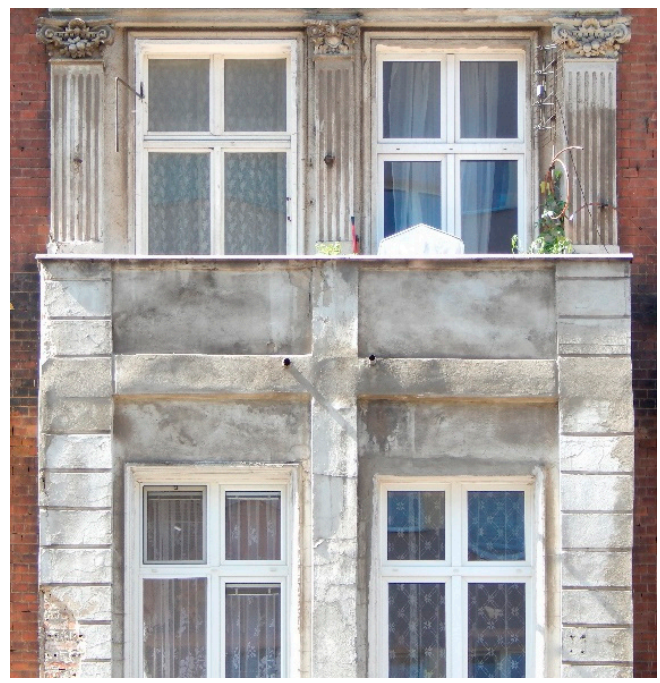

(b)

Figure 17. The tenement house, Grabiszynska St. 101, Wroclaw. Dirty elevation with damaged plaster and peeling paint (a). The oriel with damaged and uneven plaster and peeled paint. Architectural details in the Neo-Renaissance style were missing (b).

The architect proposed the beige color on the plastered surfaces, according to the "Caparol Histolith Heller Ocker 20" system, and the gray color, the "Caparol Histolith Azurit 30" system. The brick surfaces have been cleaned and impregnated (Figure 18) (Nowakowski 2014a).

\subsection{The Tenement House, Kosciuszki St. 37, Wroclaw}

The building was erected around 1850. The front façade was rebuilt around 19001910 (Witkowska 2015b). The wall of the ground floor is covered with green glazed tiles. Above the gate and the windows there are decorative motifs-ceramic, glazed moldings of cornices, and plates covered with mosaics, topped with human masks. Above the ground floor, a three-story façade was covered with lime plaster and stucco decorations (drawn and cast profiles). There are narrow vertical surfaces covered with decorative plaster (with a grooved profile) drawn vertically from the metal comb in wet mortar, supplemented with smooth plaster in the form of simple frames around the windows. 


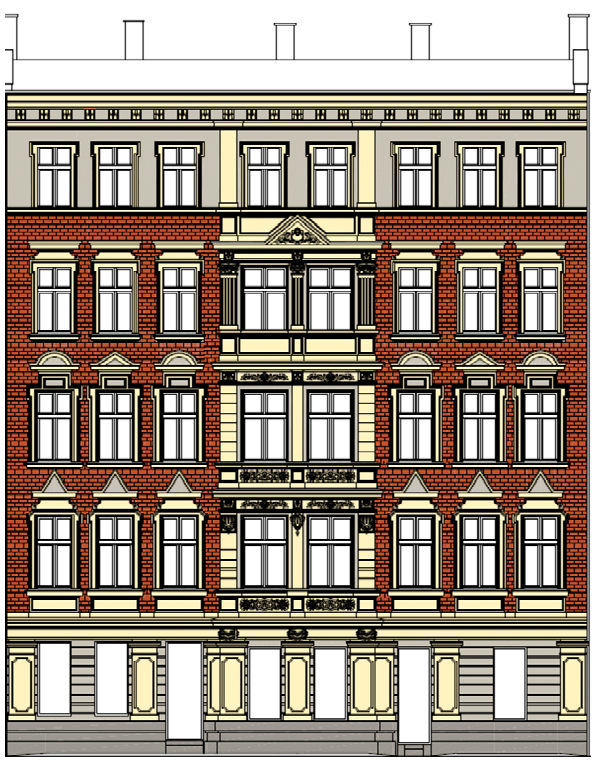

(a)

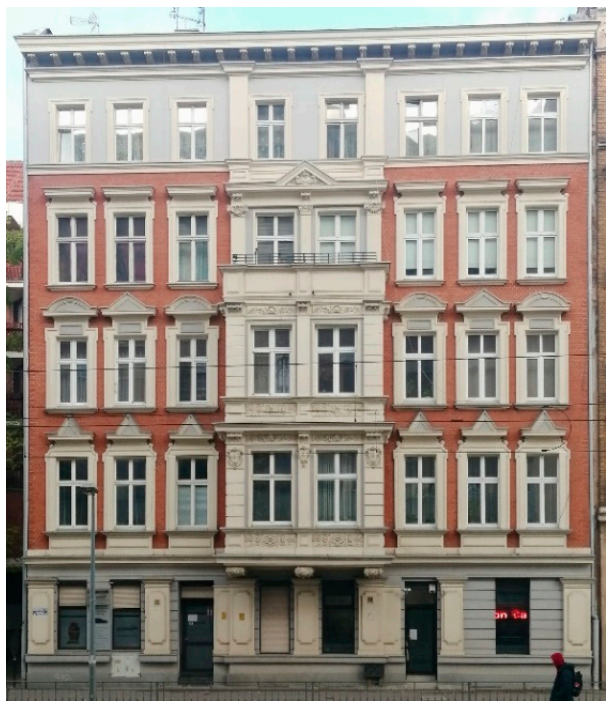

(b)

Figure 18. The tenement house, Grabiszynska St. 101, Wroclaw. Design of the front elevation colors (a) and the front elevation after renovation (b) (Nowakowski 2014a).

Iconographic research was carried out in the Building Archive of the City of Wroclaw. The archival drawings of the elevation partially matched the actual appearance of the building. However, the façades were sketchy in shape, and the architectural details were schematically presented. Comparing the archival project of the façade with the existing condition of the house allowed for the recreation of the balustrade and additional architectural details at the roof level. On-site research showed that the mosaic surfaces above the ground floor were in good condition but covered with plaster (Figure 19). At the design stage and in fragmentary stratigraphic studies, it was not possible to determine the appearance of long mosaics, located throughout the building.

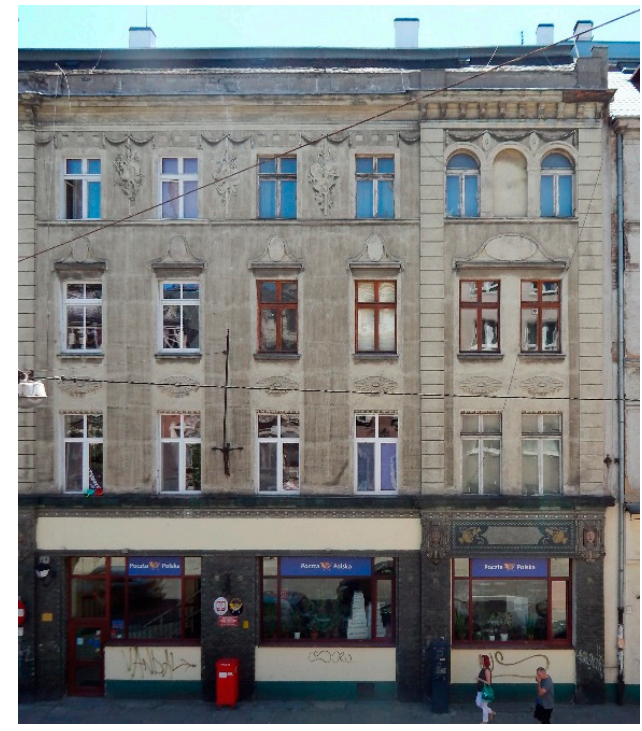

(a)

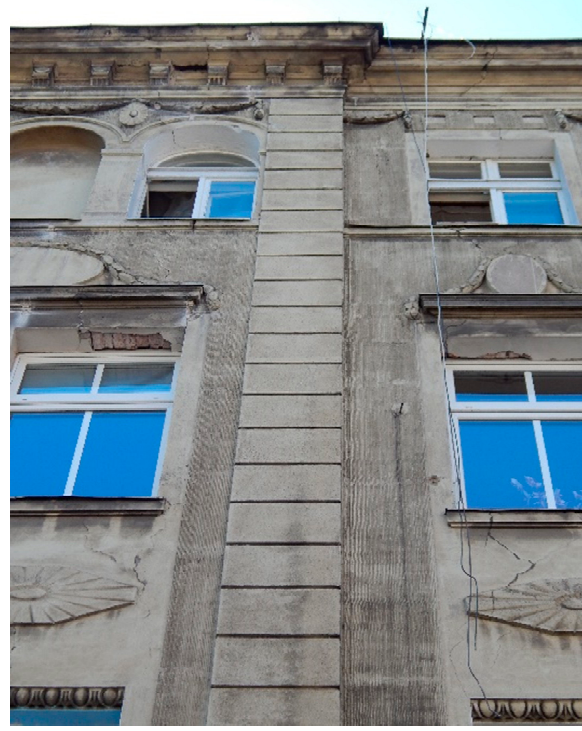

(b)

Figure 19. The tenement house, Kosciuszki St. 37, Wroclaw. Ceramic plates with a mosaic were covered with lime plaster (a). Dirty and damaged façade plaster and crooked grooved profiles (b). 
Stratigraphic studies showed the existence of the original stucco decoration layer and the painting of the façade after its reconstruction at the beginning of the 20th century. The colors were compared to the "Caparol 3Dplus" pattern. There were two shades of "Onyx 50" and "Marill 55". The later repaints made during the general renovation after World War II were extensive. The color of the windows was white. However, all windows were replaced at various times (Figure 20).

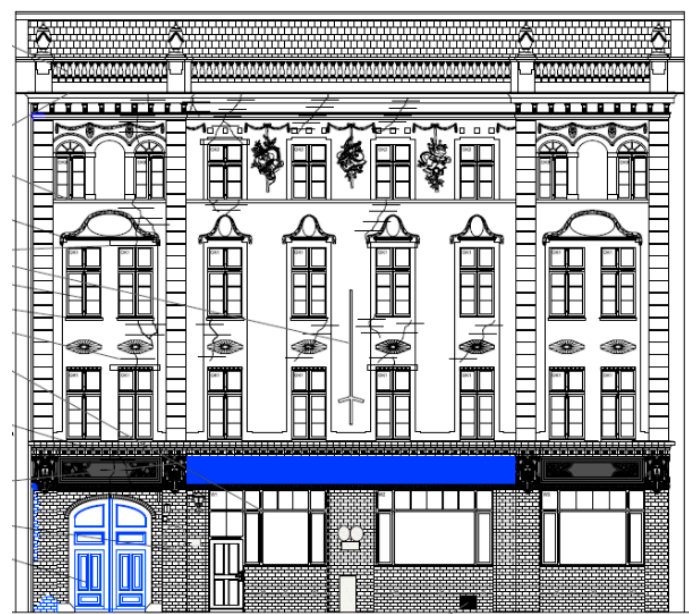

(a)

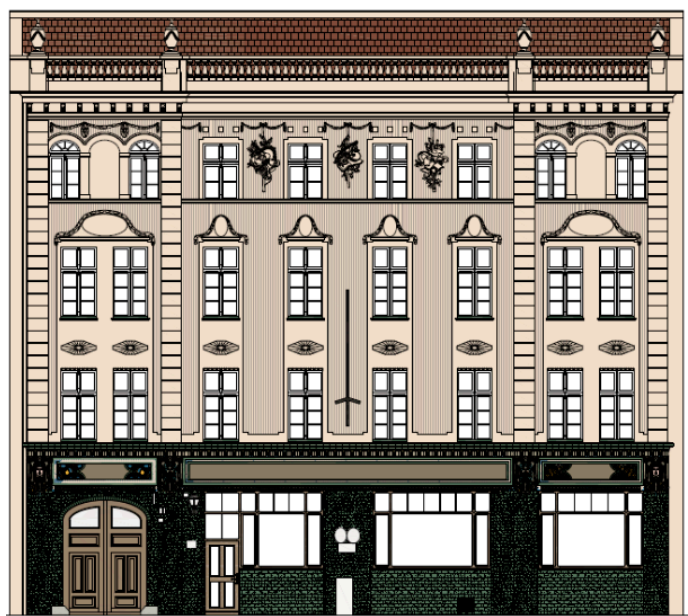

(b)

Figure 20. The tenement house, Kosciuszki St. 37, Wroclaw. Graphical concept of the renovation of the front façade (a) and the color proposal (b) (Nowakowski 2015b).

The scope of the project included a comprehensive renovation of the elevation of the front house (Nowakowski 2015b; Witkowska 2015b). Designers suggested façade colors in shades of gray-green according to the "Caparol 3Dplus" - "Onyx 50" and "Marill 55" renovation paints and the "RAL 1019" woodwork color. The colors of the rusticated avant-corps pilasters were changed to "Marill 55". The work was carried out according to the conservation recommendations, as well as the construction and details project documentation (Figure 21).

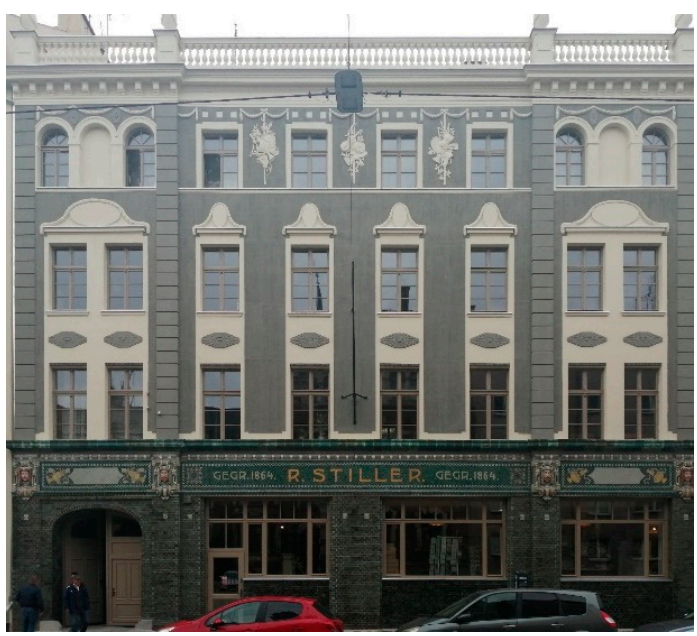

(a)

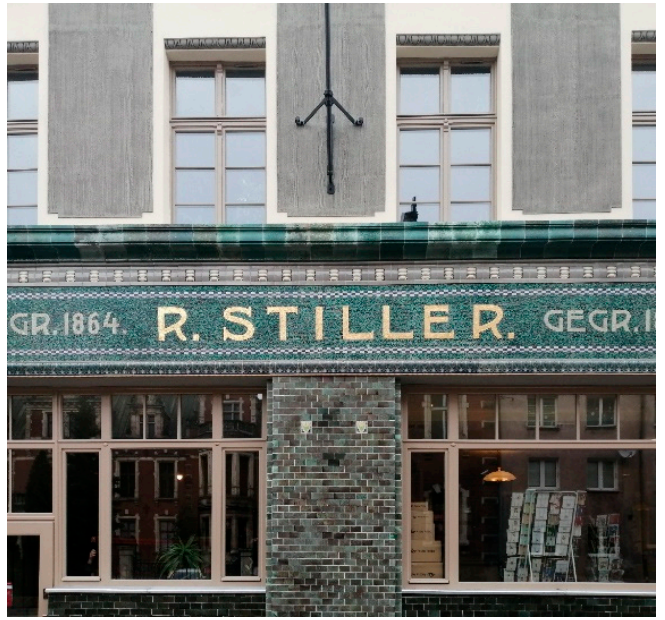

(b)

Figure 21. Colors of the front elevation after renovation (a), exposed mosaics and repaired ceramic cladding of the ground floor, replaced windows and doors (b). 
Cleaning and repainting the grooved surfaces revealed some inaccuracies in the old plastering work. The shadow pattern on the plaster structure varied, showing different shades of the color. The contractor suggested using a darker paint to compensate for the differences. Larger parts of the façade were to be painted irregularly with two paint colors. However, the representative of the Municipal Monument Conservator and the architect had rejected this controversial idea.

\section{Discussion}

Restoration of the former splendor of historical buildings requires comprehensive research and design work. The study process includes, among others, literature, iconographic, on-site, and stratigraphic research. Iconographic research is possible thanks to a well-preserved collection of old construction projects. They are available in the Building Archive of the City of Wroclaw. However, not all projects have survived. Others do not match the condition of existing buildings. Therefore, the old drawings cannot always be fully used for new tenement house renovation projects. On-site studies seem to be more helpful. They allow us to reveal the original state of the façade colors. However, these investigations are sometimes incomplete or impossible in the case of heavily damaged buildings, especially those devoid of traces of the original colors.

Conservation research and design work sometimes lead to unexpected, controversial situations during renovation work. Additional discoveries, further research, and the course of construction work verify the decisions made at the design stage. Solving such problems requires the cooperation and agreement of the participants of the investment process, especially the conservator, architect and representative of the Municipal Monuments Conservator Office.

The color of the building can be perceived differently. It can materially symbolize architecture, products, and technology. In the non-material sphere, it can symbolize the beauty, ugliness, and genius of the place and the status and character of the building owner (Donauer and Reusch 2007). The stratigraphic study ensures an objective selection of the colors of the renovated building. Its purpose is to reveal the original color of the façade. It is the basis for identifying the colors of new paints that match the original. Study, research, and design work are usually carried out by a team of architects, conservators, and other specialists. The projects presented in the article for the renovation of five tenement houses in Wroclaw were preceded by various studies, according to the requirements of the Municipal Monuments Conservator Office. The buildings represent various architectural and aesthetic styles that are characteristic in Wroclaw.

The renovation phase requires the participation of experienced construction workers. It is also necessary to use the appropriate technologies and materials for the renovation. These are traditional products (known in the old days) and modern ones, with properties better than traditional ones (including longer durability). The use of modern technologies and renovation materials protects buildings against progressive deterioration as a result of pollution and unfavorable weather conditions. Thanks to conservation techniques and materials, it is possible to restore the original condition of the elevations. As a result, tenement houses regain their former appearance, often creating a multicolored street pattern (Figure 22).

The comprehensive renovation work of the buildings allows for the preservation of the material heritage and passing it on to the next generations. Renovated buildings influence a more sensitive attitude of residents towards the history and tradition of the place. The renovated building complexes contribute to consolidating the authentic and historic image of the city in social perception.

Renovating a historical building is usually an expensive investment project. It requires financial support. Wroclaw authorities offer special renovation subsidies. They are available as part of municipal renovation programs for tenement houses and surrounding infrastructure. Funds are often obtained from the budget of the European Union. Design and implementation work should be carried out in accordance with the requirements of 
the EU administration. For example, it is necessary for a conservator to participate in the entire investment process.

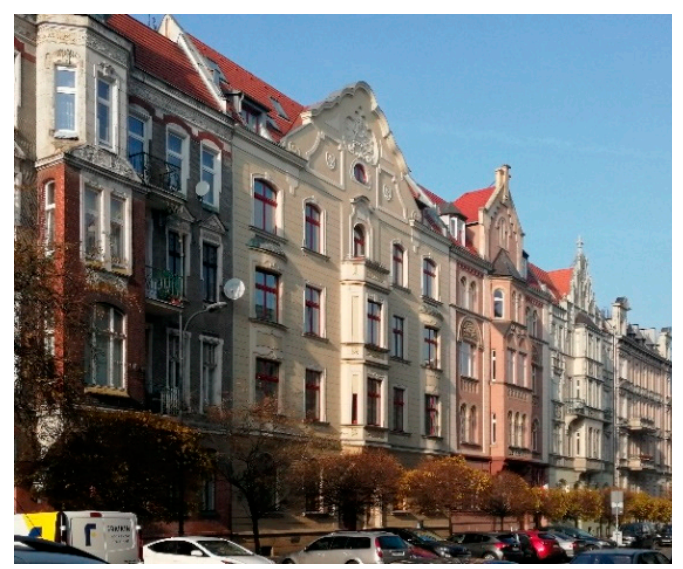

(a)

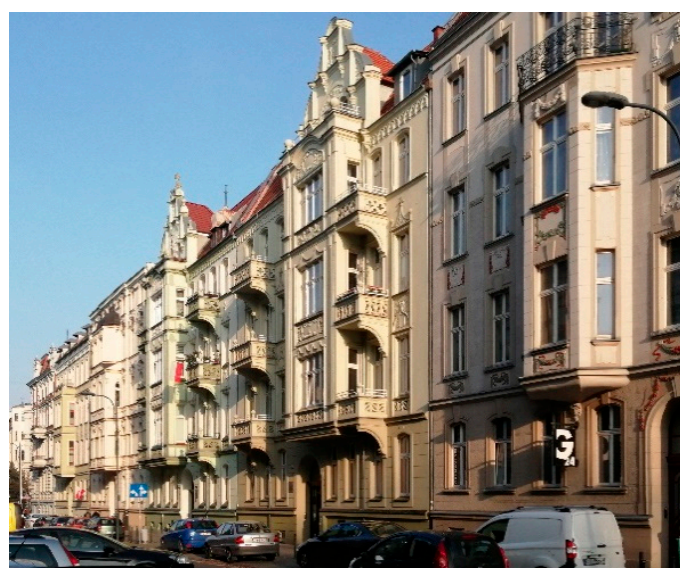

(b)

Figure 22. Restored buildings and colored tenement houses on Norwida St. in Wroclaw (a,b). Renovation work was co-financed under the large program "100 tenement houses".

Financial support of local and even international scope is in line with the laws of the European Union, as a part of development aid, targeted programs, etc. Renovations of historical façades of tenement houses in Wroclaw meet universal demands in the field of new technologies, strengthening local and international economic and cultural cooperation, etc. (EU Strategy 2021).

The restored tenement houses are noticed anew by the inhabitants of Wroclaw. It finds its expression, among other places, on social networks on the Internet. Many newly renovated buildings are positively assessed, but others are controversial. Some of the projects have even been negatively evaluated, although they were carried out with care according to conservation principles. The examples of the presented tenement houses have been positively received by residents and tourists (The Tenement House 2021).

\section{Conclusions}

The existing historical tenement houses usually have a very attractive location in the center of Wroclaw. They affect the atmosphere of the metropolis with a rich architectural history. They are also an important tourist attraction and a city-forming element.

Historical tenement houses are increasingly appreciated and entered into the Monuments Register. Due to this, they can be legally protected. Maintenance and restoration to their former condition require costly conservation work. These actions have been carried out intensively in Wroclaw for many years. Due to this, the streets and squares acquire a distinctive and multicolored character.

The World War II caused enormous damage to the buildings and technical infrastructure of Wroclaw. Most of the buildings have been rebuilt and renovated. However, many damaged old buildings were destroyed, demolished, and lost. They can be classified as permanent war losses. In this context, the surviving houses gain even greater material and cultural value. The colorful shaping of old façades and interiors is a significant aspect of the historical appearance of the city today.

The implementation of national and international programs for the revitalization of historical tenement houses enables a comprehensive design and renovation work of many tenement houses in Wroclaw. It also contributes to broadening the knowledge about the style of buildings and their original appearance. This is related to the implementation of important conservation procedures (including stratigraphic research) in the design of the renovation work. They ensure the high historical, aesthetical and technical quality 
of the renovated apartment houses. On the other hand, the administrative requirements and procedures related to obtaining and spending funds from renovation subsidies cause organizational difficulties that extend investment processes. The participation of Poland and individual regions (including cities such as Wroclaw) in the structures of the European Union guarantees the preservation and improvement of the architectural heritage.

Funding: This research received no external funding.

Institutional Review Board Statement: Not applicable.

Informed Consent Statement: Not applicable.

Data Availability Statement: Not applicable.

Conflicts of Interest: The author declares no conflict of interest.

\section{References}

Baty, Patrick. 2017. The Anatomy of Colour. The History of Heritage Paints and Pigments. London: Thames \& Hudson, pp. 26-353.

Białobłocka, Karolina. 2014. Historical colour schemes of architecture: Selected methods of presentation. In Czasopismo Techniczne. Technical Transaction, 2-A/2014. Krakow: Krakow University of Technology Publisher, pp. 3-18.

Błażko, Agnieszka, and Małgorzata Skrzypek-Łachińska. 2004. Architektura Mieszkaniowa. Wspótczesne Trendy Projektowe w Kształtowaniu Domów Mieszkalnych (Housing Architecture. Contemporary Design trends in the Design of Residential Houses). Gdansk: Publisher of Gdansk University of Technology, pp. 70-71.

Brausewetter, Artur. 1898. Das Bauformenbuch. Die Bauformen des Bürgerlichen Wohnhauses (The Design Book. The Designs of the Bourgeois Residential Buildings). Leipzig: E. A. Seemann Publisher, vol. 2, pp. 56, 59.

Chabat, Pierre. 1880. La brique et la terre cuite: Etude historique del'emploi de cesmatériaux; fabricación y usos; motivos de construcción y elección de decoración en la arquitectura de diferentes peuplas. París: Ve. A. Morel et Ces Decir, pp. 2-32.

Chitham, Robert. 2005. The Classical Orders of Architecture, 2nd ed. London and New York: Routledge, pp. 179-202.

Dokumentowanie Zabytków. 2021. Badanie i Dokumentowanie Zabytków. Available online: https:// zabytki.olsztyn.eu/badanie-idokumentowanie-zabytkow / badania-konserwatorskie.html (accessed on 30 July 2021).

Domińczak, Michał, and Artur Zaguła. 2016. Typologia tódzkiej kamienicy (Typology of a Tenement House in Lodz). Lodz: Municipal Office of Lodz Publisher, pp. 25, 32.

Donauer, Georg, and Heidrun Reusch. 2007. Fassadengestaltung mit Farbe, vom Entwurf bis zur Ausfürung. Munich: Detsche VerlagAnstalt Publisher, pp. 6-7, 20-25, 56-59.

EU Strategy. 2021. International Cultural Relations-An EU Strategy. Available online: https://eur-lex.europa.eu/legal-content/PL/ ALL/?uri=LEGISSUM\%3A4298957 (accessed on 30 July 2021).

Eysymontt, Rafał, Jerzy Ilkosz, Agnieszka Tomaszewicz, and Jadwiga Urbanik. 2011. Leksykon architektury Wrocławia (Wroclaw Architecture Lexicon). Wroclaw: Via Nova Publisher, pp. 168-69, 541-42, 609.

Gil, Milene, Ana Seruya, and Jose Agular. 2009. Colored limewash paintings in Alentejo (part 1): Pigments' identification and stratigraphic analysis (in 2004-2006). In Conservar Património. Lisbon: LNEC Publisher, vol. 10, pp. 19-38.

Gil, Milene, Casal Duarte, and Isabel Ribeiro. 2007. Colour studies in Conservation of Architectural heritage: Possibilities and difficulties of visual and colorimetric measurements and photographic reproduction of limewashing paintings. In Conference Proceedings: Materials Science Forum 2007-Porto. Évora: Colégio do Espírito Santo University of Évora Publisher, p. 83.

Gil, Milene, Maria Do Rosário, and Jose Aguiar. 2008. Limewash paintings and colored lime mortars. In Conference Proceedings: Historical Mortars Conference. Lisbon: LNEC Publisher.

Gründling, Paul. 1998. Das Bauornament in Seiner Bedeutung und Anwendung. Ein Handbuch zum Praktischen Gebrauch Beim Entwerfenvon von Bauornamenten. Holzminden: Volker Hennig Verlagsbuchhandlung, pp. 17, 64-65, 138-39.

Hueber, Friedmund. 2008. Farbgestaltung historischer Fassaden in Wien. Vienna: Stadtentwicklung Wien, pp. 35-41.

Isabey, Leon. 1867. Villas, Maisons de Ville et de Campagne. Composées sur les Motifs des Habitations de Paris Moderne, dans les Styles Des XVIe, XVIIe, XVIIIe y XIXe Siècles. Paris: A. Lévy, pp. 13-121.

Kirschke, Krystyna, and Paweł Kirschke. 2017. "Efektywne rekonstrukcje” kamienic mieszczańskich na Starym Mieście we Wrocławiu w latach 1948-1960 ("Effective reconstructions" of tenement houses in the Old Town in Wrocław in the years 1948-1960). In Dziedzictwo Architektoniczne. Rekonstrukcje i badania obiektów zabytkowych (Architectural Heritage. Reconstruction and Research of Historic Buildings). Edited by Ewa Łużyniecka. Wroclaw: Publisher of Wroclaw University of Science and Technology, pp. 42, 51.

Klasen, Ludwig. 1889. Wohn- und Geschäftshäuser. Leipzig: Baumgärtner's Buchhandlung Publisher, pp. 16-17.

Nowakowski, Przemyslaw. 2014a. Remont elewacji frontowej kamienicy przy ul. Grabiszyńskiej 101, Wrocław, projekt budowlany i wykonawczy (Renovation of the front elevation of the tenement house on Grabiszynska St. 101, Wroclaw, construction and detailed project). Unpublished work. 
Nowakowski, Przemyslaw. 2014b. Remont elewacji Frontowej, Szczytowej i Podwórzowej Oraz Remont Balkonów Kamienicy Przy Podwale 61, Wroclaw, Projekt Budowlany i Wykonawczy (Renovation of the front, gable and courtyard elevations, renovation of balconies of the tenement house on Podwale St. 61, Wroclaw, construction and detailed project). Unpublished work.

Nowakowski, Przemyslaw. 2015a. Remont elewacji frontowej kamienicy przy ul. Krasińskiego 21-23, Wrocław, projekt budowlany i wykonawczy (Renovation of the front elevation of the tenement house on Krasinskiego St. 21-23, Wroclaw, construction and detailed project). Unpublished work.

Nowakowski, Przemyslaw. 2015b. Remont elewacji frontowej kamienicy przy ul. Kościuszki 37, Wrocław, projekt budowlany i wykonawczy (Renovation of the front elevation of the tenement house on Kościuszki St. 37, Wroclaw, construction and detailed project). Unpublished work.

Nowakowski, Przemyslaw. 2017. Remont elewacji frontowej i klatki schodowej kamienicy przy ul. Kniaziewicza 17, Wrocław, projekt budowlany i wykonawczy (Renovation of the front elevation and the staircase of the tenement house on Kniaziewicza St. 17, Wroclaw, construction and detailed project). Unpublished work.

Opderbecke, Adolf, and Hans Issel. 2001. Backsteinbau und Werksteinbau: Bauformenlehre. Holzminden: Volker Hennig Verlagsbuchhandlung, pp. 33, 42, 49-50.

Rothenberg, Adolf. 1927. Die farbige Breslau. In Ostdeutsche Bauzeitung Breslau. Breslau: Paul Steinke Publisher, vol. 25, pp. 612-15.

Stratigraphic Studies. 2021. Available online: www.konserwatorzabytkow.pl/badania-konserwatorskie/badania-stratygraficzne/ (accessed on 30 July 2021).

Święcka, Ewa. 2017. Malowane elewacje architektoniczne-świadectwo historii. Badania i ich wykorzystanie w rekonstrukcjach (Painted architectural façades-A historical testimony. Research and their use in reconstructions). In Dziedzictwo Architektoniczne. Rekonstrukcje i badania obiektów zabytkowych (Architectural Heritage. Reconstruction and Research of Historic Buildings). Edited by Ewa Łużyniecka. Wroclaw: Publisher of Wroclaw University of Science and Technology, pp. 67-73.

The Tenement House. 2021. The Tenement House at Kniaziewicza St. 17 in Wroclaw after Renovation. It Is Beautiful! Available online: https:/ / www.whitemad.pl/kamienica-przy-kniaziewicza-17-we-wroclawiu/ (accessed on 30 July 2021).

Thum, Georg. 2005. Obce Miasto. Wroctaw 1945 i Potem (Foreign City. Wroclaw 1945 and Then). Wroclaw: Via Nova Publisher, pp. 388-94.

Tomaszewicz, Agnieszka. 2003. Wrocławski Dom Czynszowy 1808-1918 (Wroclaw Tenenment House 1808-1918). Wroclaw: Via Nova Publisher, pp. 21-22.

Tomaszewski, Andrzej. 1996. Fasady architektoniczne jako zagadnienie konserwatorskie (Architectural façades as a conservation issue). In Problemy Konserwacji Elewacji Budowli Zabytkowych. Materiały z Sesji Naukowej-Kraków, 9-10 Maja 1996 r. (Problems of the Façades of Conservation of the Historic Buildings Façades. Materials from the Scientific Session-Krakow, May 9-10, 1996) 5/1996. Edited by Olga Dyba. Krakow: Państwowa Służba Ochrony Zabytków (State Monuments Protection Service Publisher), pp. 7-9.

Urbanik, Jadwiga. 2019a. From "Schlesische Heimstätte" to "Die farbige Stadt"—The colour scheme of modern movement architecture in Silesia and Germany in the interwar period (1919-1933). In Architecture of the 20th Century Research and Popularisation in Gdynia and Europe. Edited by Maria Sołtysik and Robert Hirsch. Gdansk: Gdansk University of Technology Publisher, pp. 37-44.

Urbanik, Jadwiga. 2019b. WUWA 1929-2019, Wrocławska wystawa Werkbundu (WUWA 1929-2019, The Werkbund Exhibition in Wroclaw). Wroclaw: Architecture Museum in Wroclaw Publisher, p. 211.

Wandrychowska, Dorota. 2014. Elewacja Kamienicy, Wroclaw, Podwale 61. Badania Stratygraficzne i Program Prac Konserwatorskich (The Elevation of the Tenement House, Wroclaw, Podwale 61. Stratigraphic Studies and the Program of Conservation Work). pp. 3-4, 8-9, 11-13. Unpublished work.

Witkowska, Agnieszka. 2015a. Badania Stratygraficzne Elewacji Budynku Przy ul. Krasińskiego 21-23, Wrocław (The Elevation of the Tenement House, Krasinskiego 21-23. Stratigraphic Studies), p. 7. Unpublished work.

Witkowska, Agnieszka. 2015b. Badania Stratygraficzne Elewacji Budynku, Wrocław, ul. Kościuszki 37 (The Elevation of the Tenement House, Kościuszki st. 37. Stratigraphic Studies). pp. 2, 9-10. Unpublished work.

Witkowska, Agnieszka. 2017. Badania stratygraficzne elewacji budynku przy ul. Kniaziewicza 17, Wrocław (The Elevation of the Tenement House, Kniaziewicza 17. Stratigraphic Studies). pp. 3-27. Unpublished work.

Wojtysiak, Maria. 2003. Kolorystyka elewacji obiektów zabytkowych (The colors of the façades of historic buildings). In Wiadomości Konserwatorskie. Wroclaw: Dolnośląskie Wydawnictwo Edukacyjne, vol. 13, pp. 71-74.

Zeugner, Gerhard. 1965. Barwa i Człowiek (The Color and Man). Warsaw: Arkady Publisher, p. 24. 